\title{
Sedimentology, biostratinomy, and palaeoecology of an Upper Jurassic offshore sand bar complex
}

\author{
F. T. FÜRSICH and C. HEINBERG
}

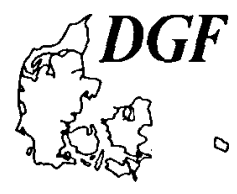

Fürsich, F. T. and Heinberg, C.: Sedimentology, biostratinomy, and palaeoecology of an Upper Jurassic offshore sand bar complex. Bull. geol. Soc. Denmark, vol. 32, pp. 67-95. Copenhagen, November, 15th, 1983. https://doi.org/10.37570/bgsd-1983-32-04

- The Aldinger Elv Member (Upper Oxfordian) of Milne Land, East Greenland, is a wedge-shaped sand body up to $90 \mathrm{~m}$ thick, intercalated between silty shales. The combination of sedimentological, biostratinomic and palaeoecological data allows a detailed reconstruction of the morphology, genesis, and palaeogeography of the bar complex. Sedimentary structures, macrobenthos and trace fossils exhibit a zonation across the sand body. The well-sorted fine-grained sands exhibit sedimentary structures, bioturbation and numerous shell beds. Three macrobenthic associations and four ichnocoenoses are distinguished. The former occur in situ as well as in various stages of reworking. Convex-upward shell pavements were formed by currents, while unsorted shell beds were generated by storms.

The sand wedge is interpreted as a shallow offshore sand complex separated from the shore by a broad swale and supplied with sediment from the north along a shoal which extended southwards, while the coastline was deflected in a southwesterly direction by a slow transgression.

Franz Theodor Fürsich, Institut für Paläontologie und historische Geologie, Ludwig-Maximilians-Universität, Richard-Wagner Strasse 10/ll. D-8000 München 2, W. Germany.

Claus Heinberg, Institut for Historisk Geologi og Palaeontologi, Østervoldgade 10, DK-1350 København K. April 25th, 1983.

\section{Introduction}

During the Jurassic, the east coast of Greenland formed the westernmost part of a seaway connecting the epicontinental seas of Europe with the Boreal Sea. Several times during this period, the sea transgressed onto the Caledonian basement in the west which, together with the intensive block faulting, particularly in the Upper Jurassic (e.g. Surlyk 1978), created a varied facies pattern with locally rapid lateral changes. One of these fault blocks formed the Jameson I and Basin, the largest of the sedimentary basins along the coast of East Greenland (Surlyk 1977). This basin is about $150 \mathrm{~km}$ wide and is bordered in the west by the Caledonian fold belt. The basin is bordered to the east by Liverpool Land, a high formed by the eastern crestal zone of the westerly dipping Jameson Land fault block (Surlyk 1977) whose crest was probably emerged during Early and Mid Jurassic time. A succession of Middle and Upper Jurassic sediments, ranging from continental and littoral to basinal deposits, is well exposed along the western edge of the basin on Milne Land, an island in the Scoresbysund, cen- tral East Greenland (Fig. 1).

A very distinct lithological unit is the Upper Oxfordian Aldinger Elv Member, a sandstone which was first described as "Pectensandstein" by Aldinger (1935) owing to the occurrence of numerous large pectinid bivalves. The sand body was mapped in 1970, together with the rest of the sedimentary rocks of Milne Land (Håkansson et al. 1971). It was then recognized that the "Pecten Sandstone" was wedge-shaped, with its greatest thickness at the east coast and thinning westwards. During the 1977 expedition of the Geological Survey of Greenland to East Greenland, the Mesozoic sequence on Milne Land was investigated in detail from a sedimentological, stratigraphical and palaeoecological point of view by T. Birkelund, J. H. Callomon, F. T. Fürsich, C. Heinberg, and S. Piasecki. Many additional data were obtained by bulk sampling the benthic fauna and by biostratinomic and sedimentological observations. A description of the rich trace fossil fauna was published by Heinberg (1974), the bivalves were monographed by Fürsich (1982) and most of the ammonites described by Sykes \& Callomon (1979). Callomon (1961) identified 


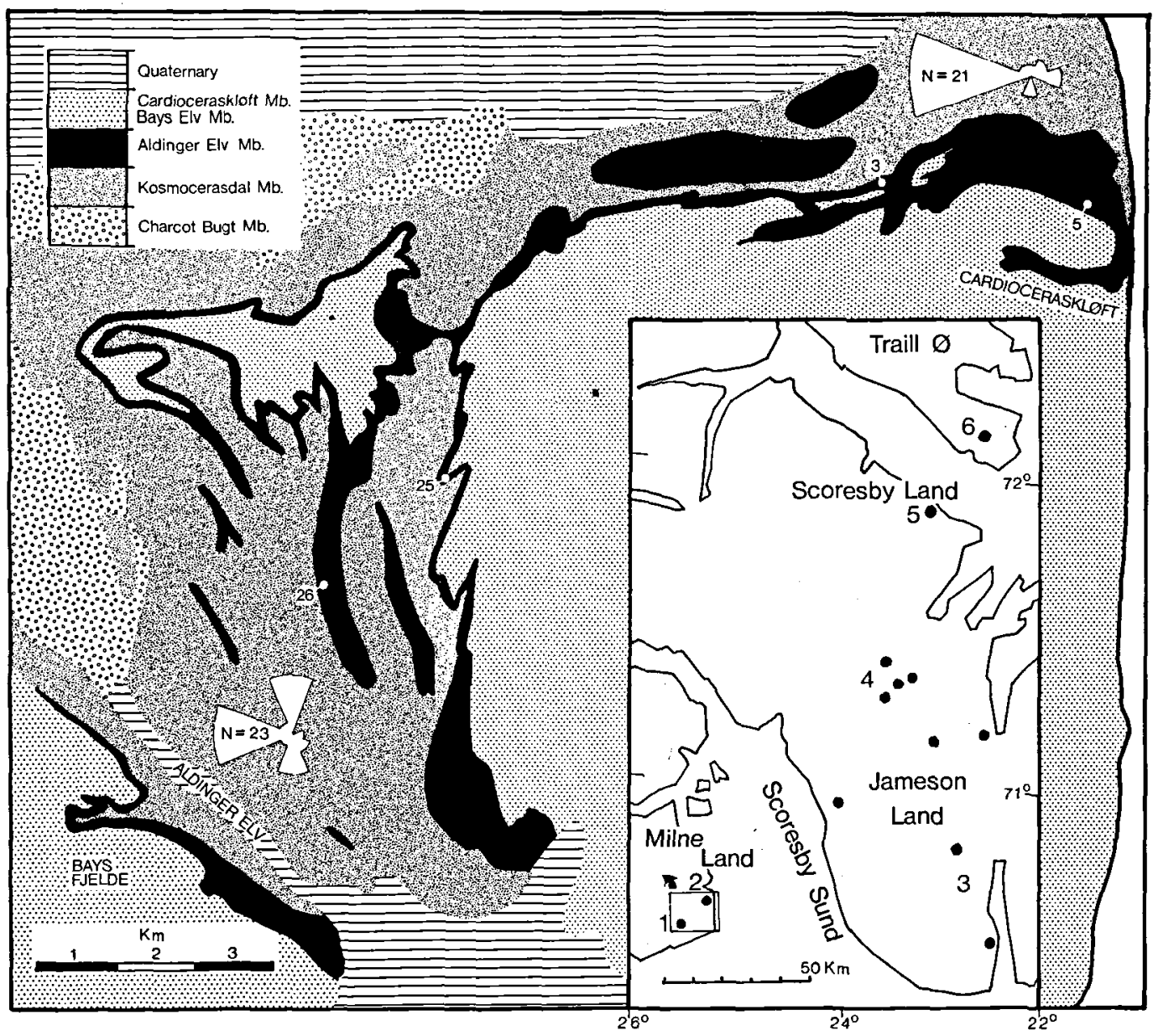

Fig. 1. Simplified geological map of part of Milne Land.

The inset map shows the Jameson Land area with numbers indicating the position of the sections of Fig. 26. Black dots are major Jurassic localities. Localities on Milne Land, mentioned in the text, are marked with numbered circles. The two rose diagrams represent the current directions measured in the northeastern and southwestern part of the Aldinger Elv sandstone respectively.

the age of the sand body as Upper Oxfordian, and recently Callomon \& Birkelund (1980) more precisely placed it in the serratum and glosense zones. They also renamed it the Aldinger Elv Member when erecting a lithostratigraphic scheme for the Bathonian to Kimmeridcian succession of Milne Land. The aim of the present study is to combine sedimentological, biostratinomic and palaeoecological data in an attempt to reconstruct the palaeogeography and environmental setting of this sand body.

\section{Geological framework}

The Aldinger Elv Member is a wedge-shaped sand body within a series of silty and sandy shales. Together, the sandstone and the shaley mudstones constitute the Kap Leslie Formation (Callomon \& Birkelund 1980), which is the southwesternmost representative of the Jameson Land Group (Surlyk 1977).

The sand body is truncated in the east by the coast of Milne Land, but the geology of the area (Surlyk et al. 1973) suggests that the sandbody probably wedged out eastwards toward the central part of the Jameson Land Basin. The 


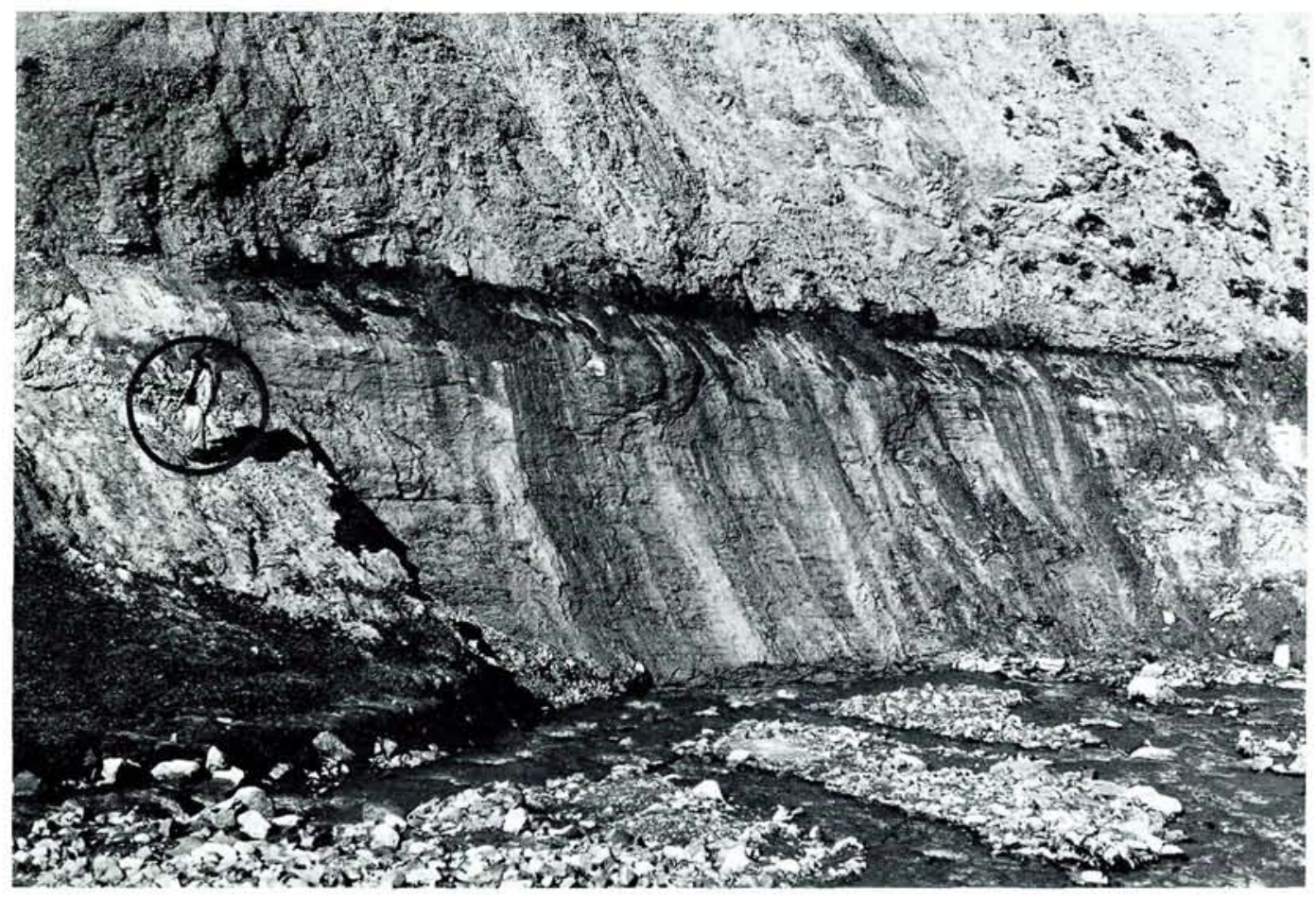

Fig. 2. Boundary between the Aldinger Elv Member (below) and the Bays Elv Member above. Cardioceraskløft. Note geologist for scale.

maximum preserved thickness is approximately $90 \mathrm{~m}$ (Håkansson et al. 1971). The member thins out westwards towards the original coastline, until it disappears in the Bays Fjelde area (Fig. 1). The upper boundary of the sandstone is sharp (Fig. 2), with an abrupt change from the mediumand fine-grained sands of the Aldinger Elv Member to the dark silty shales of the overlying Bays Elv Member. The lower boundary of the Aldinger Elv Member is gradational. The underlying Kosmocerasdal Member mudstones pass through interbedded sandstones and mudstones into the pure, in places cocquinoid, sandstones of the Aldinger Elv Member.

Biostratigraphic data (Callomon \& Birkelund 1980, Piasecki pers. comm.) suggest that the sharp upper boundary of the Aldinger Elv sandstone is isochronous, or nearly so, while the lower boundary is probably diachronous. The interbedded sand-mudstone facies that characterizes the lower boundary represents the lateral transition from the Aldinger Elv sandstones into the time equivalent part of the Kosmocerasdal mudstones in the west.
It is suggested that the Aldinger Elv sandstone was deposited as some kind of an offshore sand complex, such as an offshore shoal. The sand complex was bordered in the west (landwards) by muddy, protected marine deposits, and in the east by open marine shelf muds. The nearest equivalent to the latter is the Hare Elv Formation which is exposed on Jameson Land (Surlyk 1971), while the former is constituted by the Kosmocerasdal Member.

\section{Facies pattern}

The composite Aldinger Elv Member sequence is known from loose blocks in the scree and from the relatively few available sections, most of which are very short. The only exceptions are the Cardioceraskløft section where the uppermost 10 to $15 \mathrm{~m}$ are exposed, and an $11 \mathrm{~m}$ section in the central part of the area (loc. 25, Fig. 1). Moreover, many of the short sections and the majority of the loose blocks represent approximately the same stratigraphic level. An analysis 


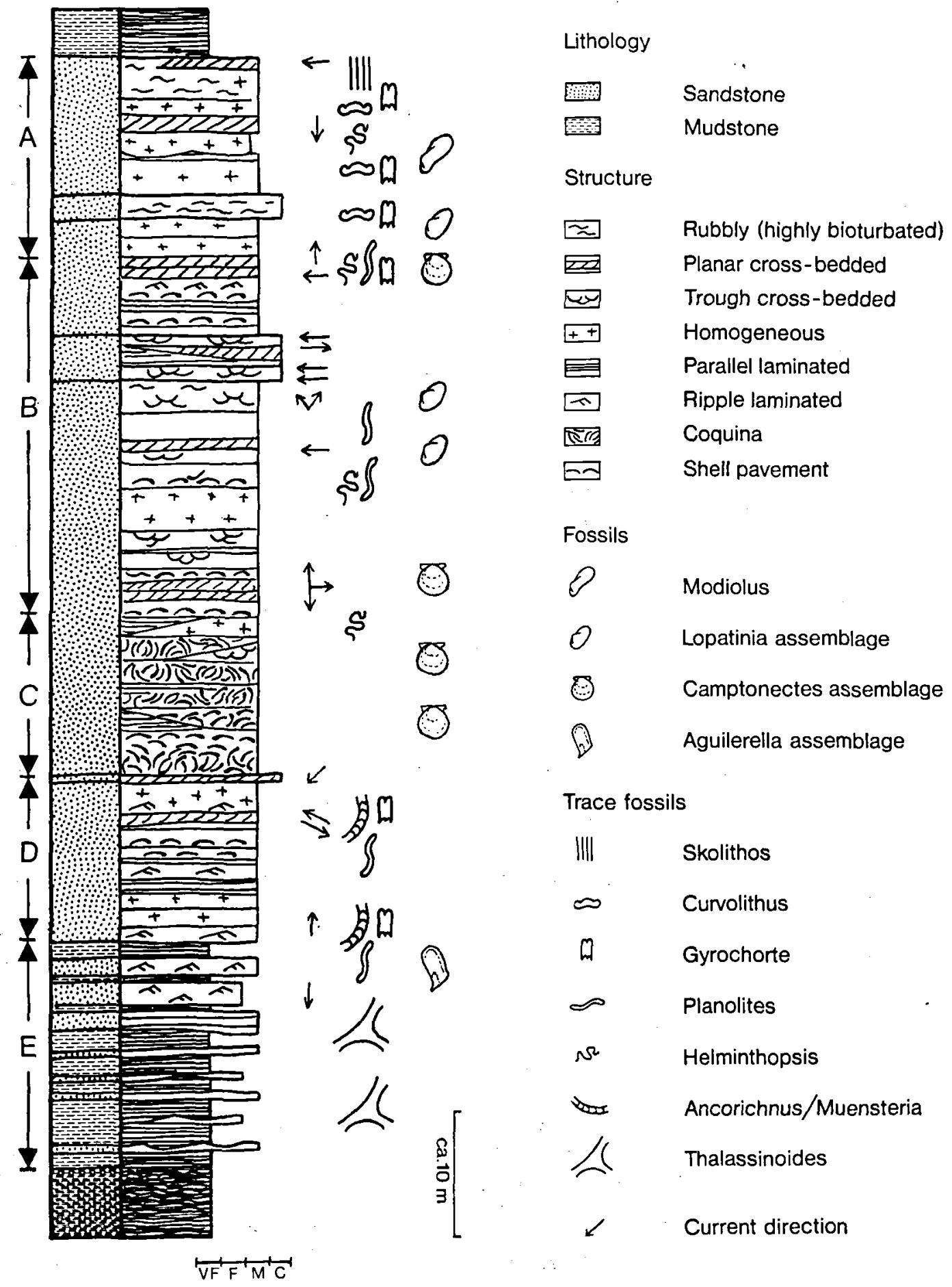

Fig. 3. Composite, somewhat idealized section of the Aldinger Elv Member. Capital letters refer to the facies of Fig. 11. Thickness of individual facies are only approximate. 


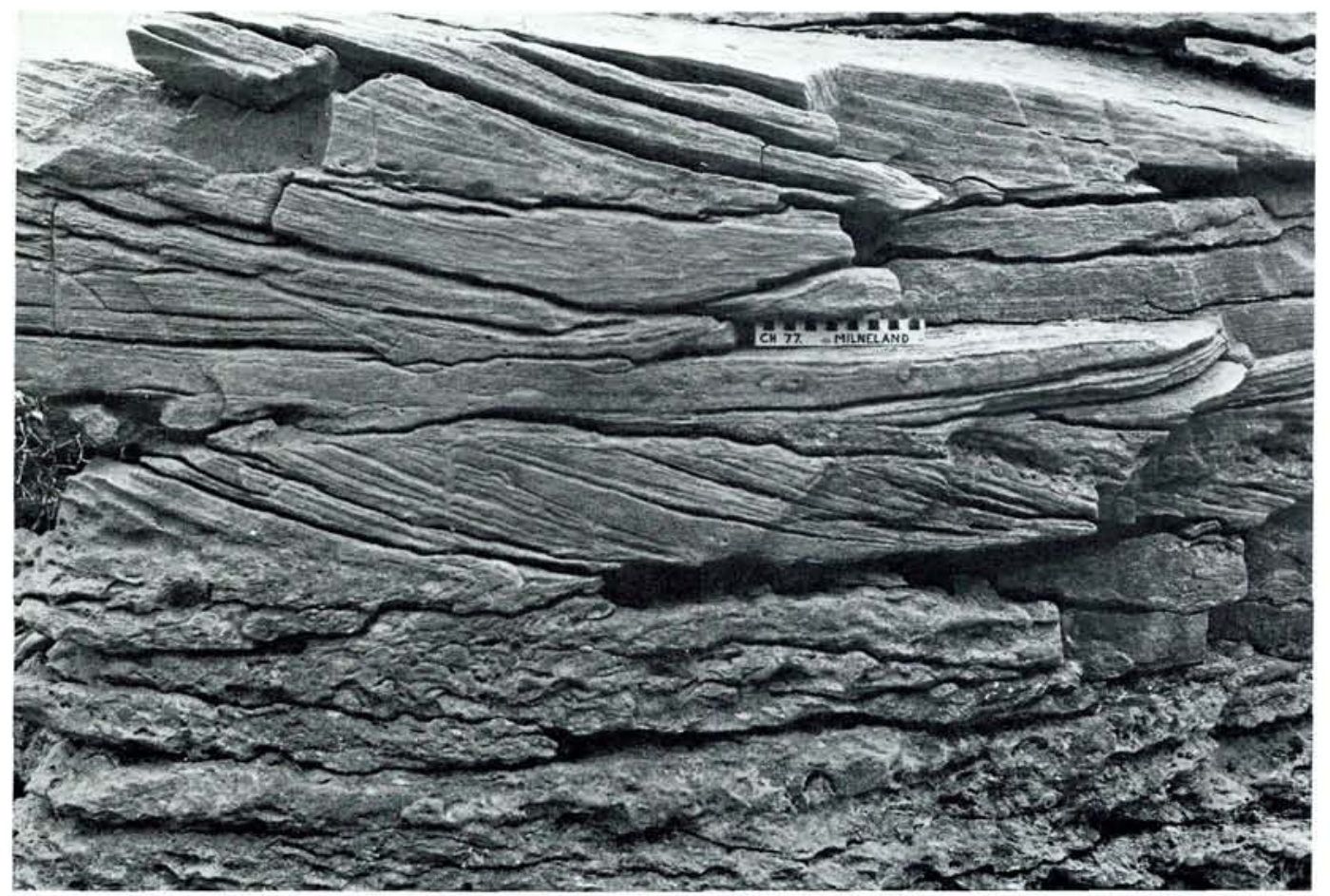

Fig. 4. Boundary between highly bioturbated sandstone, indicating a period of non-deposition, and rapidly deposited trough crossbedded sandstone. The latter is devoid of biogenic structures except for a few escape-burrows in the lowermost unit. Facies B, one $\mathrm{km}$ north of locality 3 (see Fig. 1). Scale in $\mathrm{cm}$.

of the spatial facies pattern is therefore of limited value. Thus, the sand body must be treated as a whole, focusing on the lateral distribution of the facies types and with some emphasis on the vertical shift actually found in sections or in loose blocks. The observations are compiled in the composite section shown in Fig. 3.

\section{Lithofacies and transport directions}

The distribution of lithofacies shows a distinctive lateral change from east to west.

The upper 10-15 m, which are exposed in Cardioceraskløft on the east coast, are dominated by structureless fine-grained sandstones. The lack of visible structures is probably due to the good sorting of the sand, but may also be due to bioturbation. A few horizons of crossbedded sandstones occur together with highly bioturbated, often medium-grained sandstones (Fig. 4). Along the northern exposures, planar and trough crossbedded sandstones occur frequently together with parallel laminated and small-scale crossbedded sandstones. The sandstones are mostly fine-grained, but medium and coarse varieties are also present.

The central part of the area is dominated by extensive coquinas up to one metre thick (Fig. 5) interbedded with trough-crossbedded and parallel-laminated sandstone. Structureless and small-scale crossbedded fine-grained sandstones are found further to the east, stratigraphically below the coquinas. Finally, interbedded platy sandstones and shaley mudstones dominate to the west where the sand body wedges out. The sandstones are structureless, parallel laminated or show small-scale crossbedding. Planar large-scale crossbedded sandstones and lenticular bedding are found within the shaley mudstone.

The number of measureable in situ crossbeds is very restricted, limiting transport direction measurements to 44 . Westerly transport directions dominate in the northeastern part of the area, 


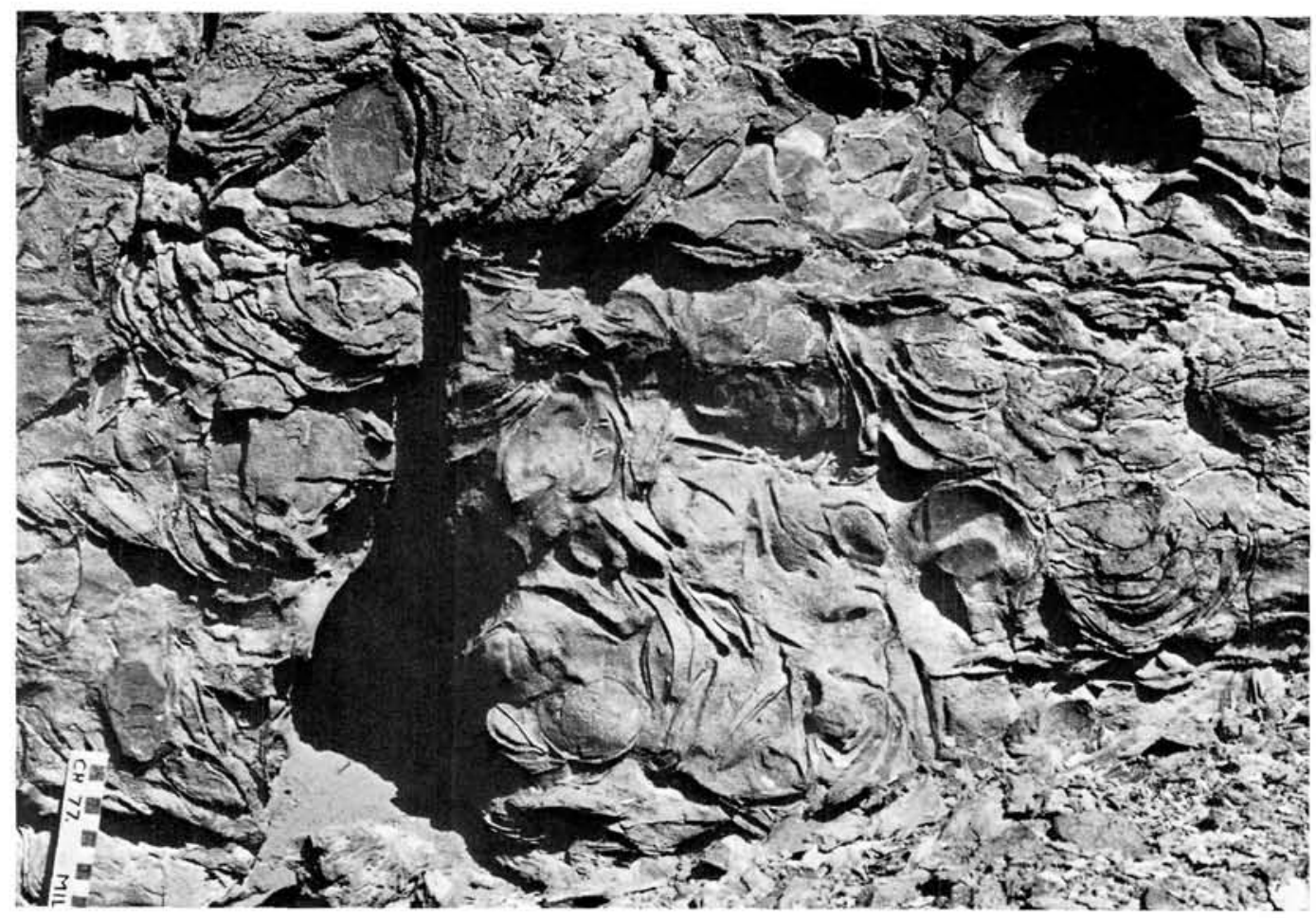

Fig. 5. Coquina made up largely of shells of the bivalve Campionectes. Facies C, close to locality 25 (see Fig. 1). Scale in $\mathrm{cm}$.

while in the central area a north-south bimodal tendency, in addition to a distinct westerly direction, prevails (Fig. 1).

\section{Trace fossils}

The ichnofauna of the Aldinger Elv Member consists of 12 different ichnogenera, each represented by a single ichnospecies.

As a whole, the assemblages are very similar to those found elsewhere in the Jurassic and Cretaceous marine sandstones of the Jameson Land Basin (Birkelund \& Heinberg 1974).

Most of the traces belong to well established ichnogenera, which do not require much comment, but a few will be discussed in some detail (For trace fossil taxonomy, see appendix).

The trace fossils show a clear distribution pattern. Some traces, regarded as "ichno-specialists", are restricted, while others are widely distributed and therefore "ichno-generalists". It is possible to distinguish four ichnocoenoses, three of which are defined by one or more of the "specialists", while the fourth is composed entirely of "generalists".

The ichnocoenoses are: the Curvolithus, the Anchorichnus, the Planolites, and the Thalassinoides ichnocoenosis (Fig. 7). The first three are confined to the sandstone proper, whereas the Thalassinoides is associated with the interbedded mudstone-sandstone part of the sequence.

The ichnocoenoses are taxonomically identical, or nearly so, to the trace fossil assemblages in the sandstones of the Pelion Member of Jameson Land (Heinberg \& Birkelund, unpubl. data), in the Hartz Fjeld Sandstone of Milne Land (Heinberg 1973), and in the finer parts of the Charcot Bugt Sandstone (Håkansson et al. 1971). This underlines the recurrent nature of the associations, and thus their ecological significance.

The Curvolithus ichnocoenosis (Fig. 7 I). This coenosis consists of Curvolithus and Gyrochorte, with Planolites next in importance. In addition, a variety of traces are restricted to this 


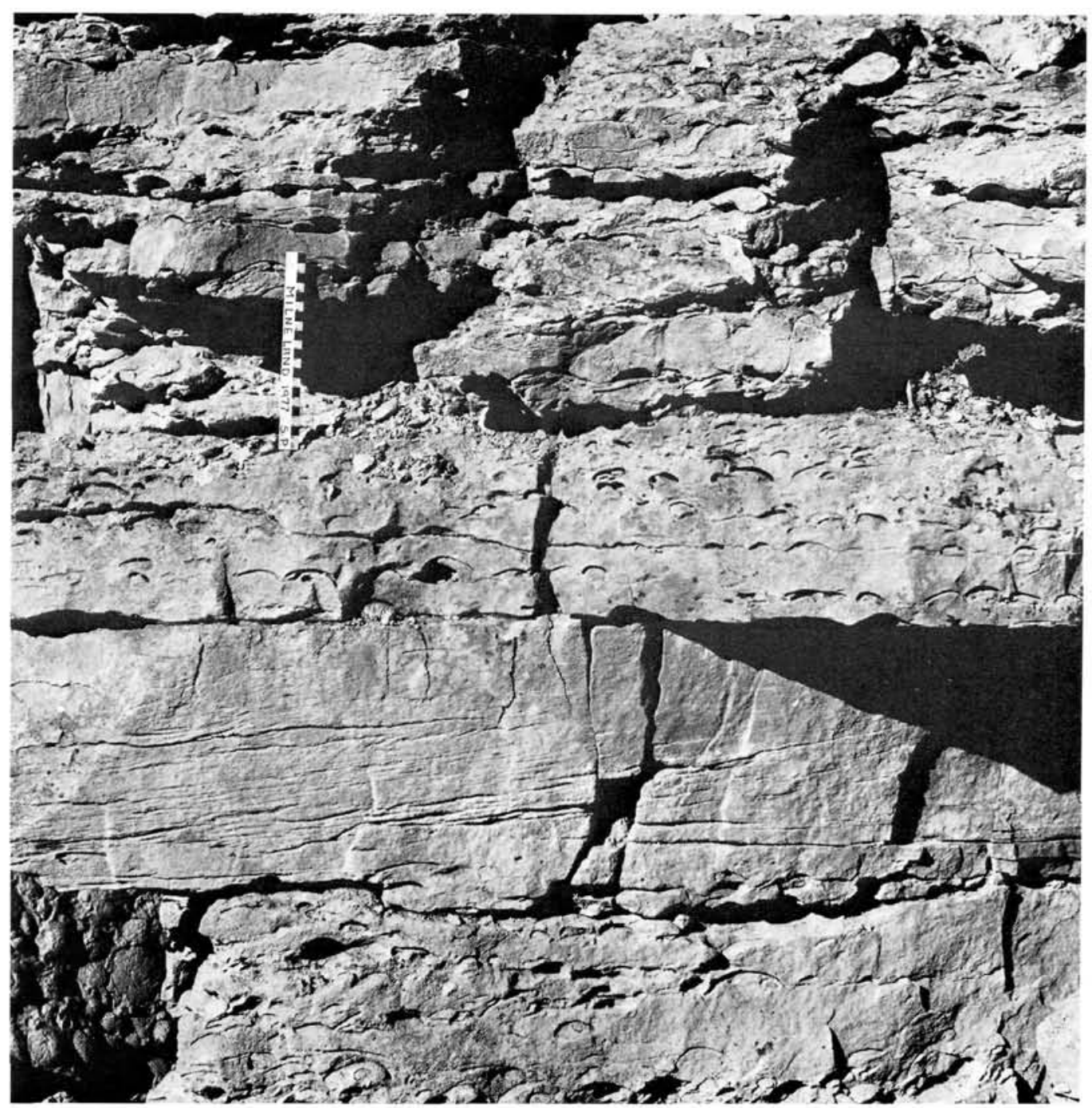

Fig. 6. Outcrop showing current-orientated (convex up) Camptonectes shells in parallel laminated sandstone separated by unfossiliferous low angle tabular crossbedded sandstone. Facies C, locality 25 (see Fig. 1). Scale in cm.

ichnocoenosis, such as Skolithos, Arenicolites and Gyrophyllites. The Curvolithus ichnocoenosis reflects the activity of a trophically diverse fauna of carnivorous, infaunal and epifaunal deposit- and suspension-feeders. The high degree of bioturbation ('rubbly' sandstones, Fig. 8) indicates a high faunal density and/or long intervals of non-deposition (Howard 1975). The trophically diverse fauna indicates intermediate environmental conditions with water agitation sufficient for the requirements of suspension-feeders, but weak enough to allow settling of the finer organic de- tritus essential for deposit-feeders. The presence of at least one infaunal carnivore indicates an additional infauna, which served as prey. The high faunal diversity and the degree of bioturbation indicate that the Curvolithus sandstones represent the oceanward slope of the sand body, at depth and wave conditions characteristic of the upper offshore zone. This corresponds well to the extensive distribution of this ichnocoenosis in the Pelion sandstone, where it can be followed for more than $100 \mathrm{~km}$ along particular ammonite horizons. 


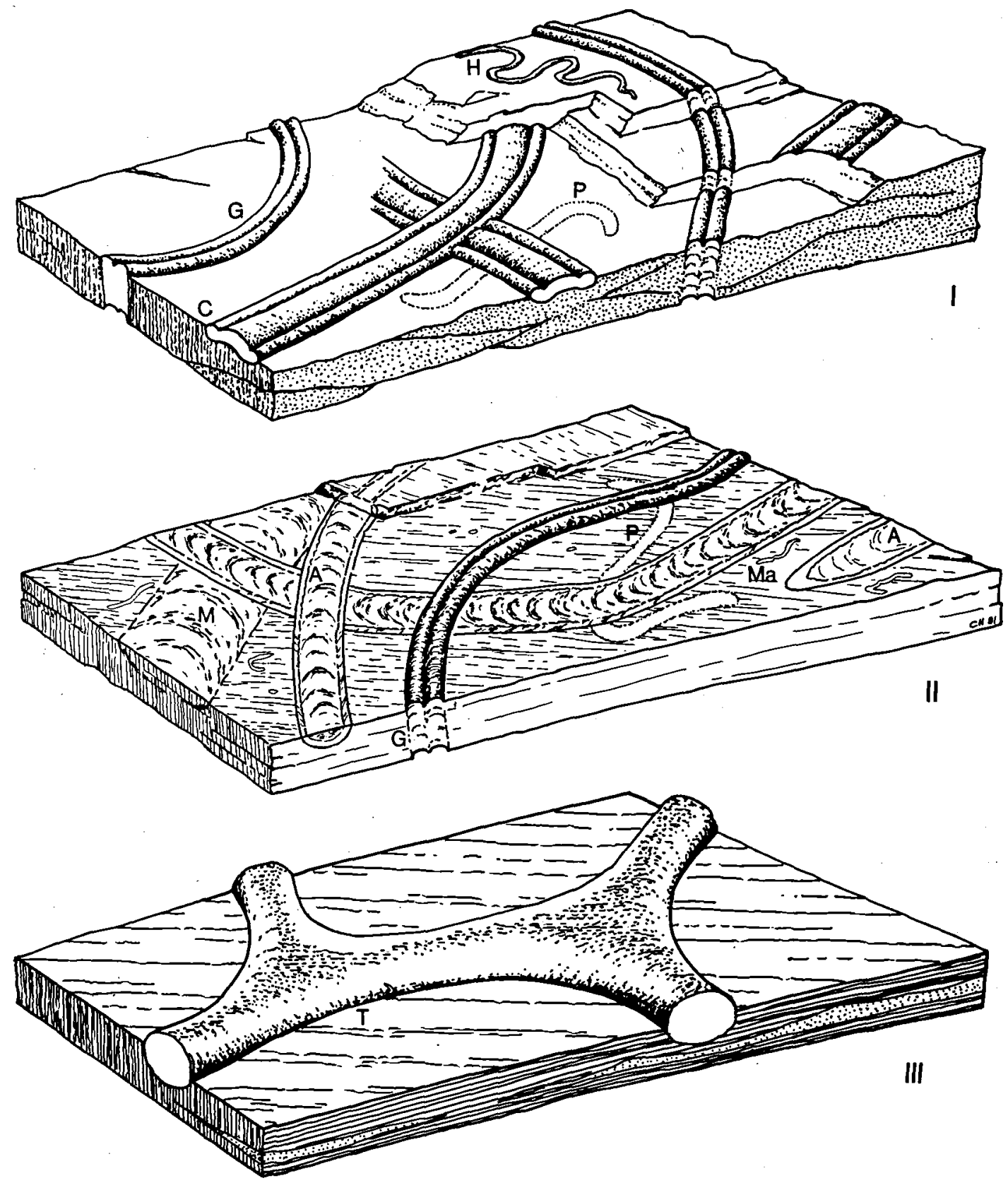

Fig. 7. The three major ichnocoenoces: I. The Curvolithus ichnocoenosis, II. The Ancorichnus ichnocoenosis, and III. The Thalassinoides ichnocoenosis.

The Planolites ichnocoenosis is not shown, but corresponds to the Curvolithus ichnocoenosis with Curvolithus itself missing. A: Ancorichnus ancorichnus, C: Curvolithus sp., G: Gyrochorte sp., H: Helminthopsis sp., P: Planolites sp., M: Muensteria sp., Ma: Macaronichnus segregatis, T. Thalassinoides suevicus. 


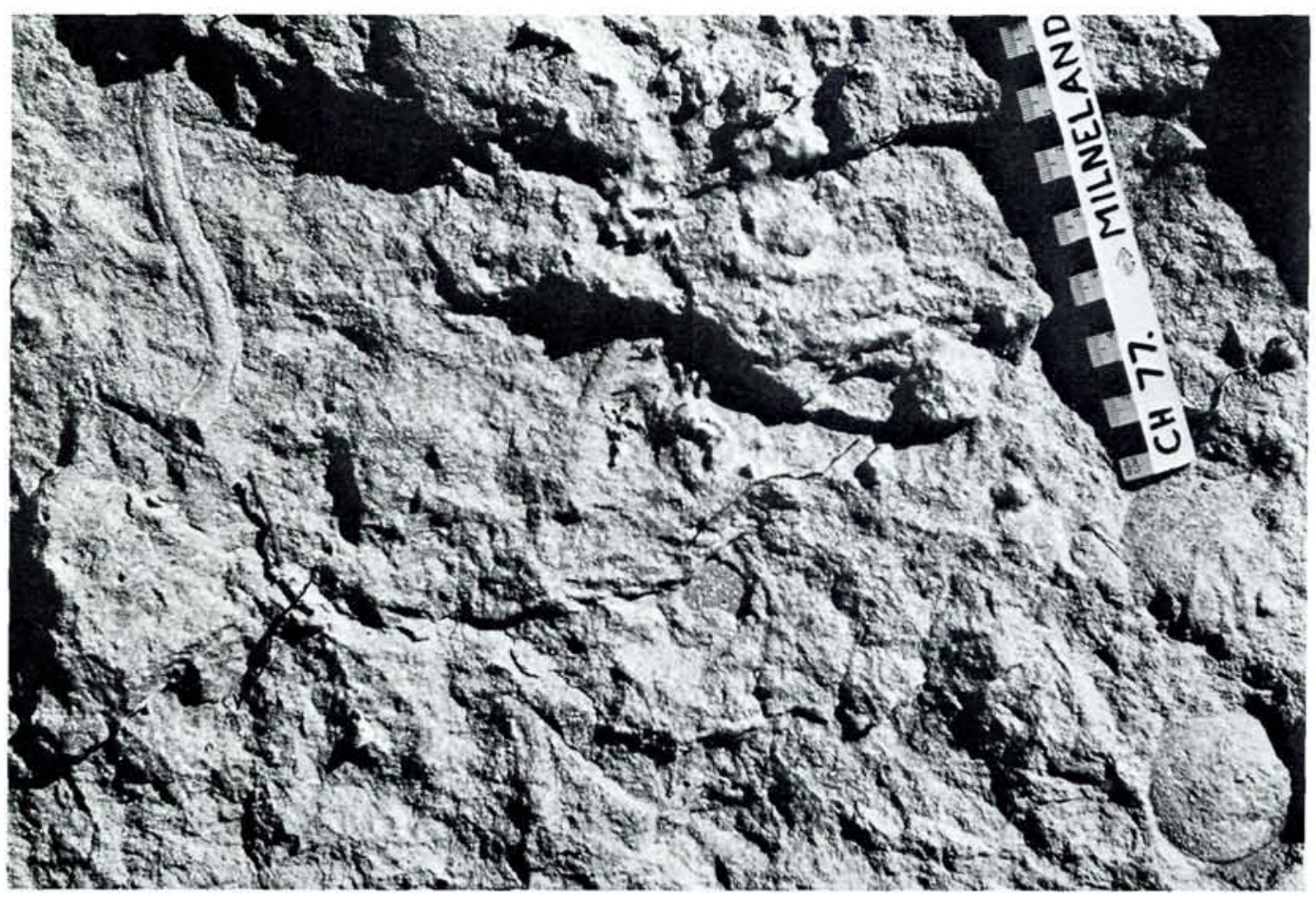

Fig. 8. Rubbly sandstone with Curvolithus. Facies A, Cardioceraskløft. Scale in cm.

In Recent examples from Sapelo Island (Dörjes 1972) and the Gulf of Gaeta (Dörjes \& Hertweck 1975) this is the zone of maximum faunal diversity and of the highest abundance of carnivorous gastropods, the possible producers of the Curvolithus trail. Lithologically this zone is characterized by bioturbated and parallel laminated sand, which is also the case with the Curvolithus sandstones.

The Ancorichnus ichnocoenosis (Fig. 7 II). The trophic composition of this ichnocoenosis is very uniform. All the traces, such as Ancorichnus, Gyrochorte, Muensteria, Planolites and Macaronichnus were made by deposit- feeders (Heinberg 1974) indicating that the content of organic matter in the sediment was relatively high. The backfill traces of this ichnocoenosis indicate a low energy environment permitting organic detrital particles to settle out of suspension. A close analogy in the Recent is the lower offshore facies found at Sapelo Island (Hertweck 1972), the German Bay (Reineck et al. 1968), and the Gulf of Gaeta (Hertweck 1973), where different sea urchins produce backfill structures in a variety of sediments, ranging from coarse-grained relic sands to silty muds (Dörjes \& Hertweck 1975). The Ancorichnus ichnocoenosis is also found in the Pelion Member of Jameson Land where it occupies the thin basal transition to the underlying Sortehat mudstone (Heinberg \& Birkelund, 1984).

The Planolites ichnocoenosis. - The coenosis consists of the same species as the Curvolithus ichnocoenosis, except for Curvolithus itself. First in importance is Gyrochorte followed by Planolites (Fig. 9) and Helminthopsis (Fig. 10). The coenosis is thus primarily defined by the absence of traces of possible carnivores. This might indicate a somewhat more exposed position of the sediments as compared to the Curvolithus ichnocoenosis.

The Thalassinoides ichnocoenosis. - This "association" (Fig. 7 III) hardly justifies the description coenosis, since it only involves a single ichnospecies, Thalassinoides suevicus. It is found in connection with interbedded sandstones and mudstones. The large, semi-permanent horizontal tunnel systems indicate a quiet environment 


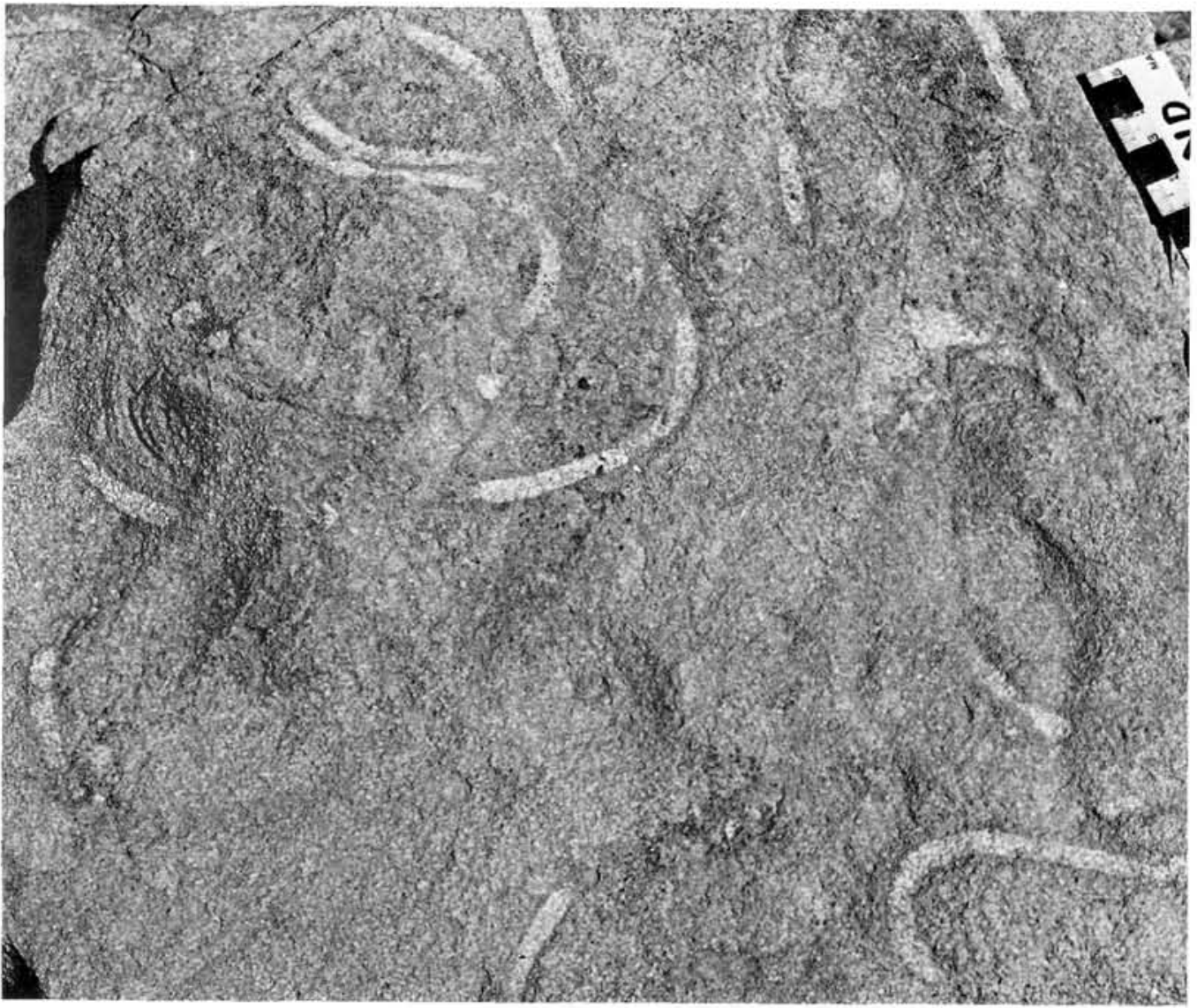

Fig. 9. Planar sandstone with Planolites. Facies B, valley north of Cardioceraskløft. Scale in $\mathrm{cm}$.

with only little reworking. This ichnocoenosis probably represents the lowest energy level of the four under discussion.

Lateral distribution of the trace fossils. -

As is the case with the lithofacies distribution, the areal distribution of the ichnocoenoses shows a clear regional pattern (Fig. 11).

The Curvolithus ichnocoenosis is found only in the thickest part of the sandstone body in the east. It dominates the upper $10 \mathrm{~m}$ of the sandstone in Cardioceraskløft and the scattered exposures in the next valley to the north, a slightly lower stratigraphic level. The sandstone exposures further to the north and west are dominated by the Planolites ichnocoenosis, while the Ancorichnus ichnocoenosis is restricted to the central and western part of the sandstone area, the Vestelv and neighbouring valleys.
The Thalassinoides ichnocoenosis only occurs at the lower transitional boundary between the Aldinger Elv sandstone and the underlying Kosmocerasdal mudstone. This boundary is exposed primarily in the western part of the area, for example around Bays Elv and locality 26.

A similar relationship between the Thalassinoides ichnocoenosis and the sandstone-mudstone transition facies is found on Jameson Land, where the same coenosis is closely associated with the transition between the Pelion sandstone and the overlying Fossilbjerget mudstone (Birkelund \& Heinberg 1974). 

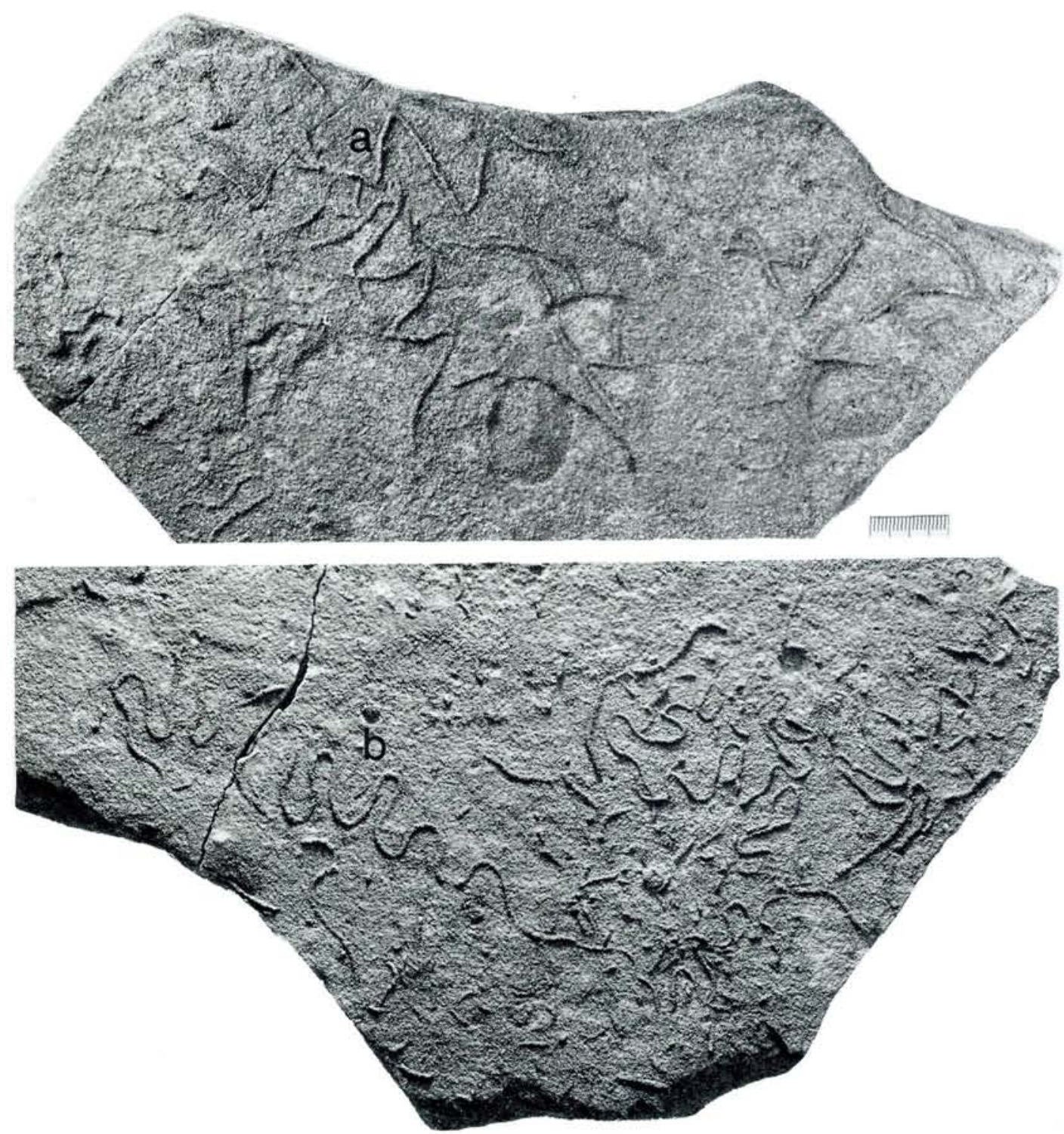

Fig. 10. Parallel laminated sandstone with Urohelminthoida (a) and Helminthopsis (b). Locality 3. Scale $2 \mathrm{~cm}$.

\section{Palaeoecology and biostratinomy of the macrobenthos}

Autochthonous and parautochthonous associations

A detailed description of the associations will be published elsewhere (Fürsich, in prep.), but their trophic nuclei are presented in Table 1. The numerous shell beds yielded three associations which differ clearly in their species composition and ecology of their components. They are the Lopatinia callomoni association, the Camptonectes broenlundi association, and the Ditrupa nodulosa association.

The three associations are characterized by 1) the total lack of deposit-feeders amongst the hard-shelled taxa except for possibly Ditrupa, 2) the dominance of bivalves, except again in the 


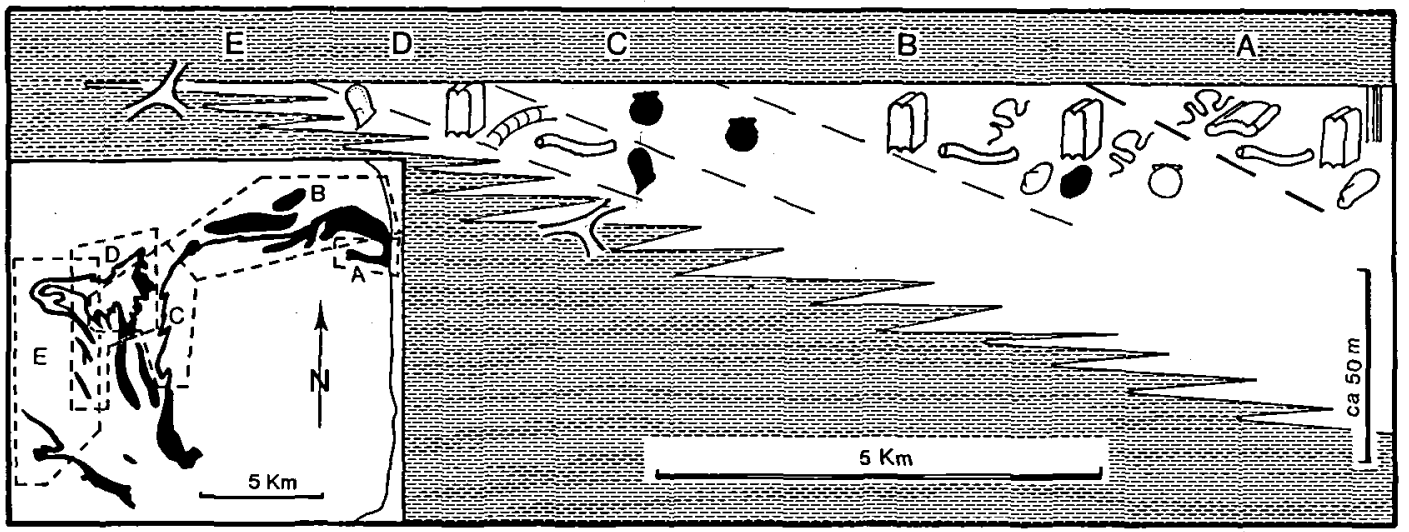

Fig. 11. Synthesis of observations on the Aldinger Elv sandstone. Five facies (A-E; see text and fig. 3) are recognised. Their approximate areal extent is shown on the inset map (compare with Fig. 1), and their supposed distribution within the sand wedge is indicated by dashed lines. For key of symbols see Fig. 3. Black symbols indicate reworking.

case of the Ditrupa nodulosa association, and 3) a relatively low evenness and species richness (Fig. 12 ). Of the three, the $D$. nodulosa association exhibits the lowest diversity values and consists nearly exclusively of epifaunal elements. The epifauna also dominates the C. broenlundi association, while shallow burrowing faunal elements prevail in the L. callomoni association (Fig. 13). All associations occur in well-sorted fine-grained sandstones.

Interpretation. - The well sorted sediment and

\section{Table 1}

Trophic nuclei of the autochthonous associations EF = epifaunal free living; $S B=$ shallow burrowing; $D B=$ deep burrowing; $S=$ suspension-feeder, $D=$ deposit-feeder.

rel.abund. pres. $\%$ lifehabit

The Lopatinia callomoni association

3 collections

567 specimens

Lopatinia callomini

53.08

100

SB S

Arctica syssollae

20.63

100

SB $S$

Pleuromya zakharovi

7.05

66.7

DB S

The Camptonectes (Boreionectes) broenlundi association

3 collections

1056 specimens

$\begin{array}{lrrr}\text { Camptonectes (B.) broenlundi } & 72.35 & 100 & \text { EF S } \\ \text { Arctica syssollae } & 8.05 & 100 & \text { SB S }\end{array}$

The Ditrupa nodulosa association

1 collection

246 specimens

Ditrupa nodulosa
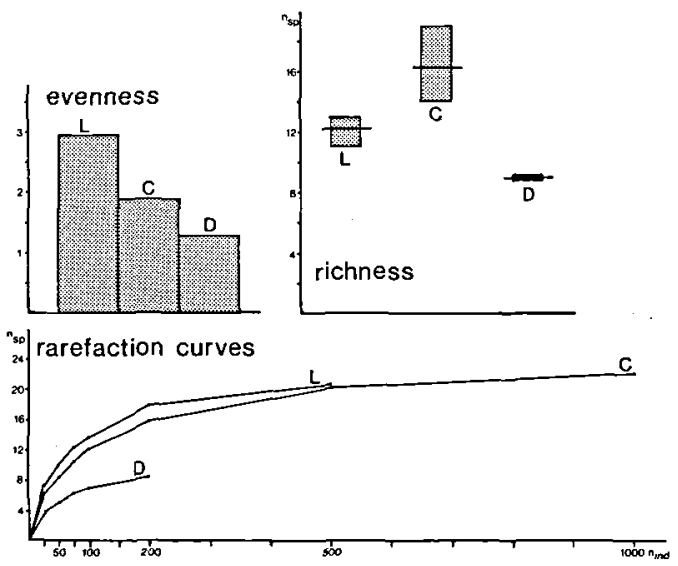

Fig. 12. Diversity data for the Lopatinia callomoni (L), Camptonectes broenlundi (C), and Ditrupa (D) associations. Evenness values calculated according to MacArthur (1972: 197). Species richness expressed by the number of species, and rarefaction curves constructed according to Sanders (1968).

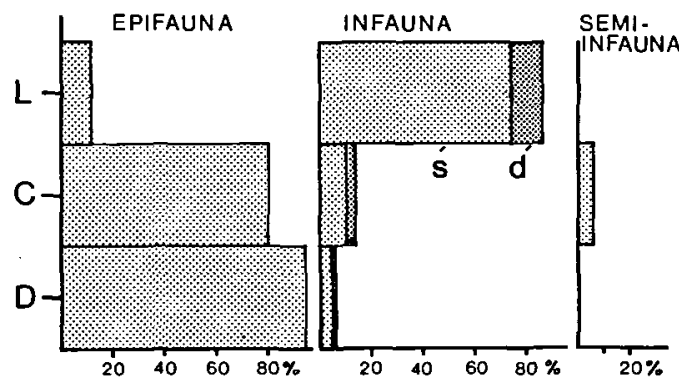

Fig. 13: Percentage of epifauna, infauna, and semi-infauna of the Lopatinia callomoni (L), Camptonectes broenlundi (C) and Ditrupa (D), associations.

s: Shallow burrowing, d: Deep burrowing. 


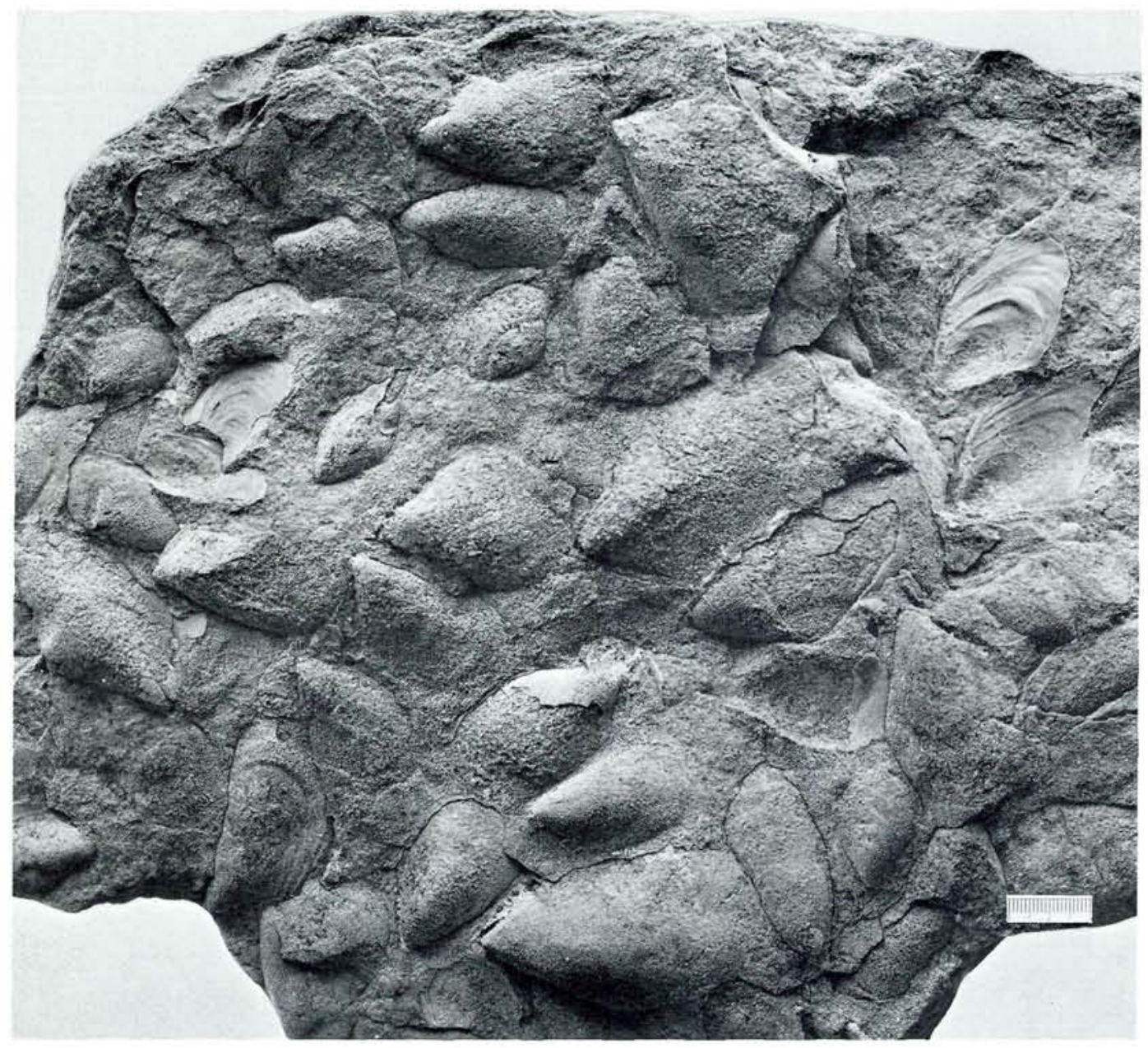

Fig. 14. Current-oriented shell pavement of Aguilerella aldingeri. Valley east of Bays Fjelde, height $200 \mathrm{~m}$. Scale $2 \mathrm{~cm}$. See also Fig. 15.

the sedimentary structures suggest an environment at least intermittently influenced by waves and/or currents. This assumption is supported by the fauna in which deposit-feeders (with the exception of trace fossils and Ditrupa) are absent and forms adapted to life in a high energy environment dominate. For example, the shallow burrowing bivalve Lopatinia callomoni most probably was a rapid burrower owing to its laterally compressed form and weak ornament. The same might have been true of Arctica syssollae in analogy to the Recent Arctica islandica (Saleuddin 1964; for opposite view see Schäfer 1962:423). The large scallop Camptonectes (Boreionectes) broenlundi, a planoconvex form, rested with its flat right valve on the substrate and surely was able to swim. A byssate mode of life in the adult stage seems less likely (Fürsich 1982). The polychaete Ditrupa nodulosa probably lived on the substrate. It is known that these animals are able to escape sedimentation (possibly with the help of tentacles (Wilson 1976)). Little is known of the life habits of Recent Ditrupa apart from that they are epifaunal and possibly feed from the sediment surface (Taylor 1978:322).

Commonly, bivalves (e.g. Lopatinia, Arctica) and Ditrupa are moderately thick-shelled. This is also true of several deep-burrowing forms such as Tancredia magna and Pleuromya zakharovi. Thus the most common elements of the benthos 
exhibit one or the other adaptation to life in or on a shifting high energy substrate. Similar environments today are inhabited by only few specialized animals. The low diversity of the three associations from Milne Land is in agreement with this observation. An analysis of the diversity data and life habit groups allows tentative differentiation between the three associations: Judging from its very low diversity, the $D$. nodulosa association may have lived in the least stable parts of the shoal under the highest environmental stress. The $C$. broenlundi and $L$. callomoni associations represent environments of somewhat reduced stress whereby the relatively high evenness value of the $L$. callomoni association identifies it as having been subject to the comparatively least environmental stress.

In conclusion, the three associations charaterise a shallow-water, mobile substrate and were subject to a varying degree of environmental stress.

\section{Assemblages}

The three benthic associations commonly occur as transported assemblages. Their biostratinomic history, caused largely by selective transport, will be discussed in a later section. Here, two assemblages are briefly described of which one is the transported relic of an association (the Aguilerella aldingeri assemblage) and the other one (the Pentacrinites assemblage) may, in fact, represent an autochthonous association.

The $A$. aldingeri assemblage forms a shell bed 5 $\mathrm{cm}$ thick in which over 90 percent of the fauna are represented by disarticulated $A$. aldingeri (Fig. 14). This fossil is a byssate bakevelliid bivalve which probably lived in clusters on the sea floor. The shells show a preferred orientation and most of them are in a stable current position (convex-up) (Fig. 15). Apart form A. aldingeri, only five other species were encountered, all of them occurring as disarticulated shells. The shell bed probably represents the relic of an $A$. aldingeri association whereby, through selective transport, $A$. aldingeri became enriched in relation to other faunal elements. In fact, $A$. aldingeri has been found in situ as small clusters in the wes-

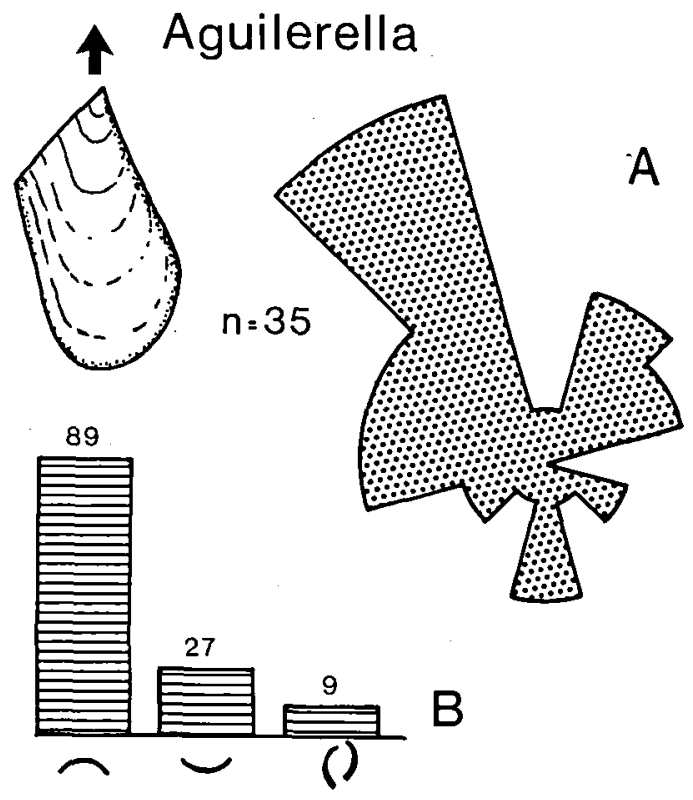

Fig. 15. Plan-view (A) and side view (B) orientation of shells in monotypic pavement of Anguilerella aldingeri. Valley east of Bays Fjelde.

ternmost part of the sandstone belt. However, no detailed data on this occurrence are available.

The Pentacrinites assemblage consists of nests and thin lenticles of disarticulated ossicles and, more rarely, of articulated portions of arms, stems and crowns. Apart from the crinoids, only rare Ditrupa and bivalves are present. Faunal density and diversity are very low. Considering how rapidly echinoderm skeletons (particularly crinoids) disintegrate after death and considering the ease with which echinoderm skeletal elements are transported, owing to their low specific gravity, the presence of apparently autochthonous or only slightly transported crinoid fragments can be explained only by rapid burial after the death of the animals. However, as it cannot be excluded that the crinoids were uprooted somewhere else and transported into their burial place before death (and thus allochthonous), they are here classified as an assemblage rather than an association.

Similarly to the crinoids, ophiuroids and echinoids may be common at some levels, again preserved as articulated specimens, indicative of rapid burial. 


\section{Influence of reworking on faunal composition and diversity.}

\section{The Ditrupa association}

On the slopes of the Nordøst Elv (locality 3) Ditrupa nodulosa is a common faunal element. Rarely, it occurs autochthonously as the $D$. nodulosa association, more often it reflects various states of reworking. An increasing degree of reworking is indicated by a decrease in diversity, increase in the degree of sorting, the formation of thin shell layers and an increase in uniform shell orientation (Fig. 16). The final product is a mono-specific shell layer of Ditrupa which exhibits a pronounced orientation pattern (Fig. 17). Such accumulations occur as densely packed lenses, as thin sheets on the foresets of large-scale crossbeds and in ripple troughs. In all cases, the orientation pattern suggests wave influence whereby the Ditrupa shells were orientated normal to wave movements (compare Nagle 1967). A similar break-up of the $D$. nodulosa association can be observed at locality 5 (Fig. 18). In addition, $D$. nodulosa occurs there as admixture to other benthic associations such as the $C$. broenlundi or L. callomoni associations which are either autochthonous or themselves exhibit some degree of transport.

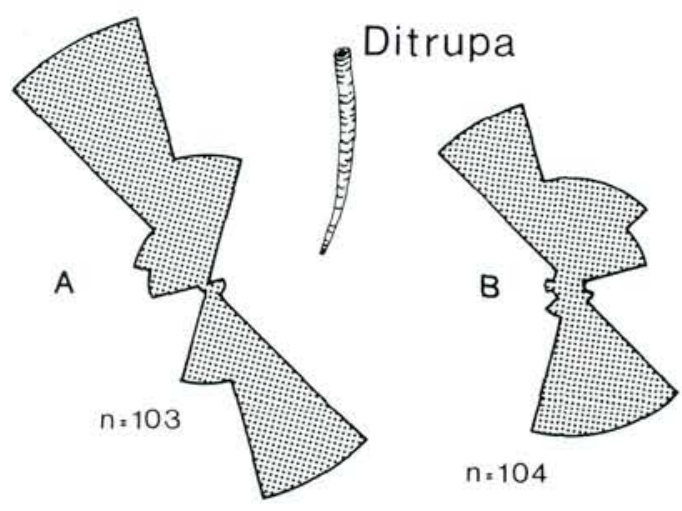

Fig. 16. Bedding-plane orientation of tubes of the polychaete Ditrupa nodulosa. A: Monotypic shell layer, exhibiting a high degree of transport and sorting. B: Parautochthonous assemblage with Ditrupa as dominating faunal element. Locality 3 .

The Lopatinia association

At locality $3, L$. callomoni occurs frequently either scattered in the sediment or in shell beds usually 5 to $10 \mathrm{~cm}$ in thickness. In both cases, some degree of reworking is evident as no faunal elements occur in life position. Less common are shell beds, $25 \mathrm{~cm}$ in thickness, which exhibit a zonation whereby the degree of articulation decreases and the percentage of convex-up orientated shells increases towards the top (Fig. 19).

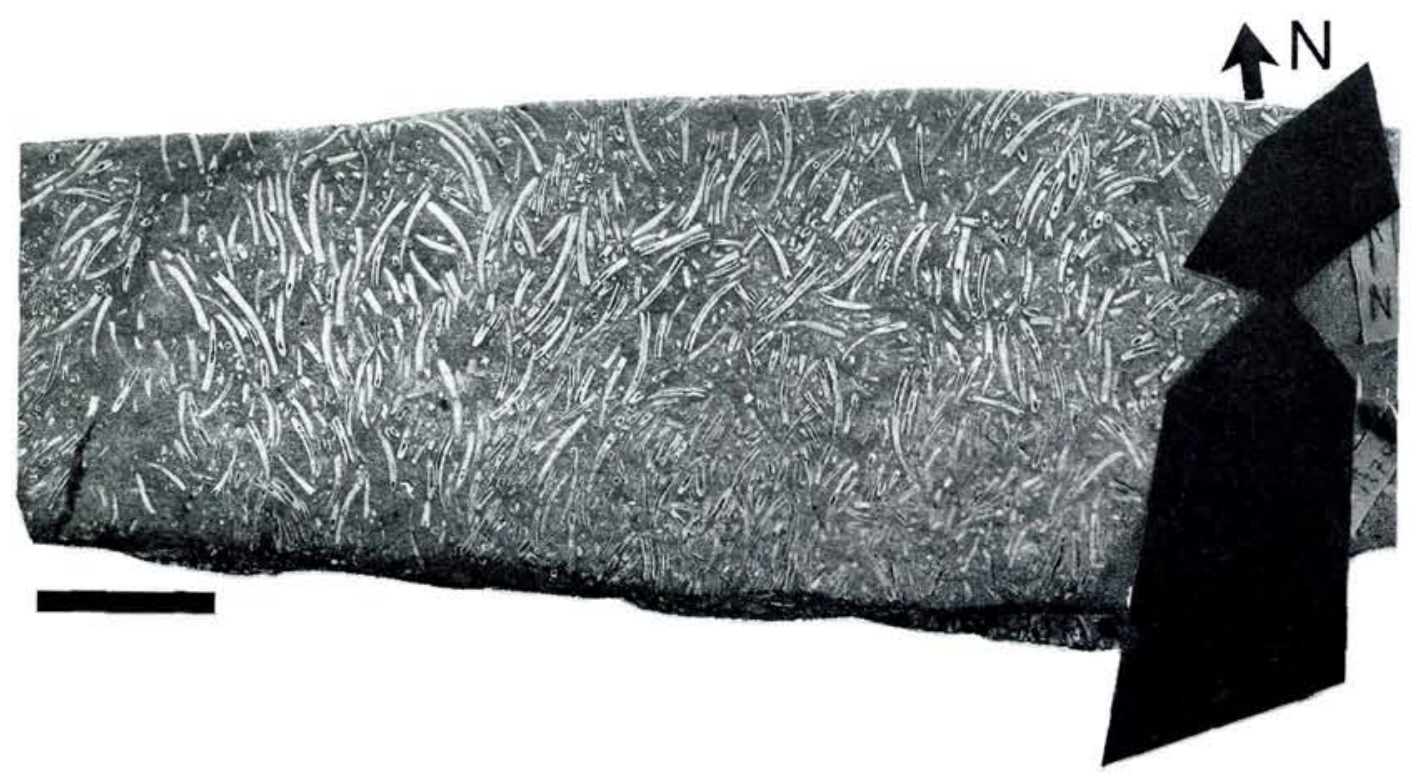

Fig. 17. Bedding plane view of Ditrupa shell bed. The tubes are oriented normal to current direction. Scale $5 \mathrm{~cm}$. $226 \mathrm{readings}$. 


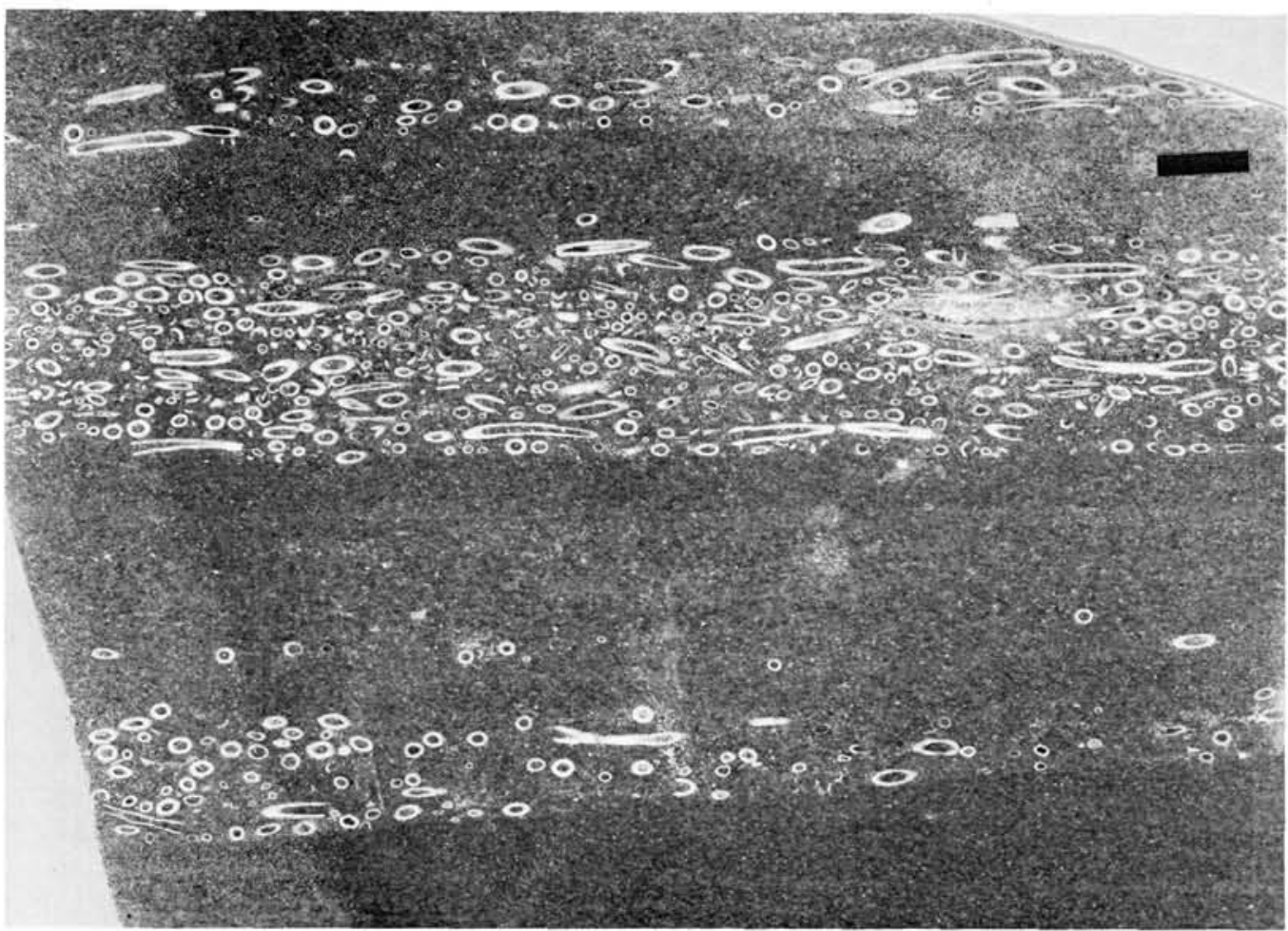

Fig. 18. Section through crossbedded sandstone with three thin shell beds of Ditrupa, oriented largely normal to current direction. Valley north of Cardioceraskløft. Scale $1 \mathrm{~cm}$.

The presence of a bioturbated zone at the base of such shell beds indicates a temporary stable substrate which was colonised and possibly led to the formation of an autochthonous shell bed which then may have been reworked in situ, most likely by storms. Storms probably are also responsible for the zonation within such shell beds, leading finally again to deposition of crossbedded sands. In all shell beds the percentage of articulated specimens, orientation patterns, lack of sorting and good preservation favours short-term reworking only, without extensive lateral transport. Samples A and B in Fig. 20 therefore represent examples of the parautochthonous $L$. callomoni

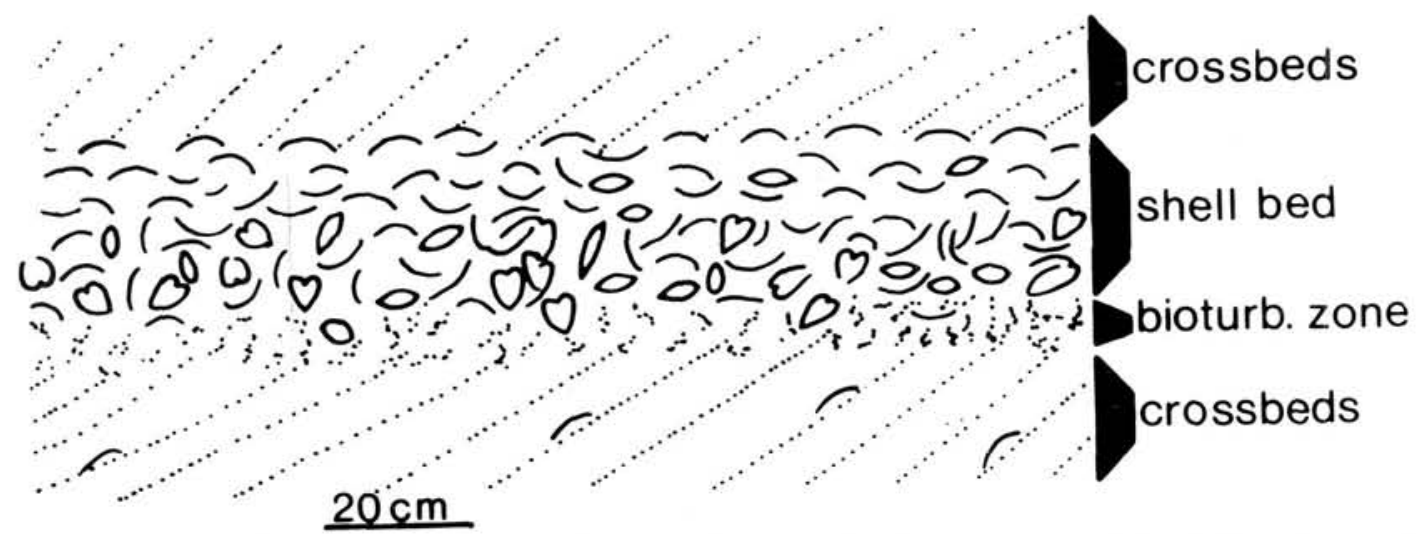

Fig. 19. Field sketch of shell bed of the Lopatinia callomoni association. Note the high percentage of articulated shells at the base of the shell layer. For further explanation see text. Locality 3. 


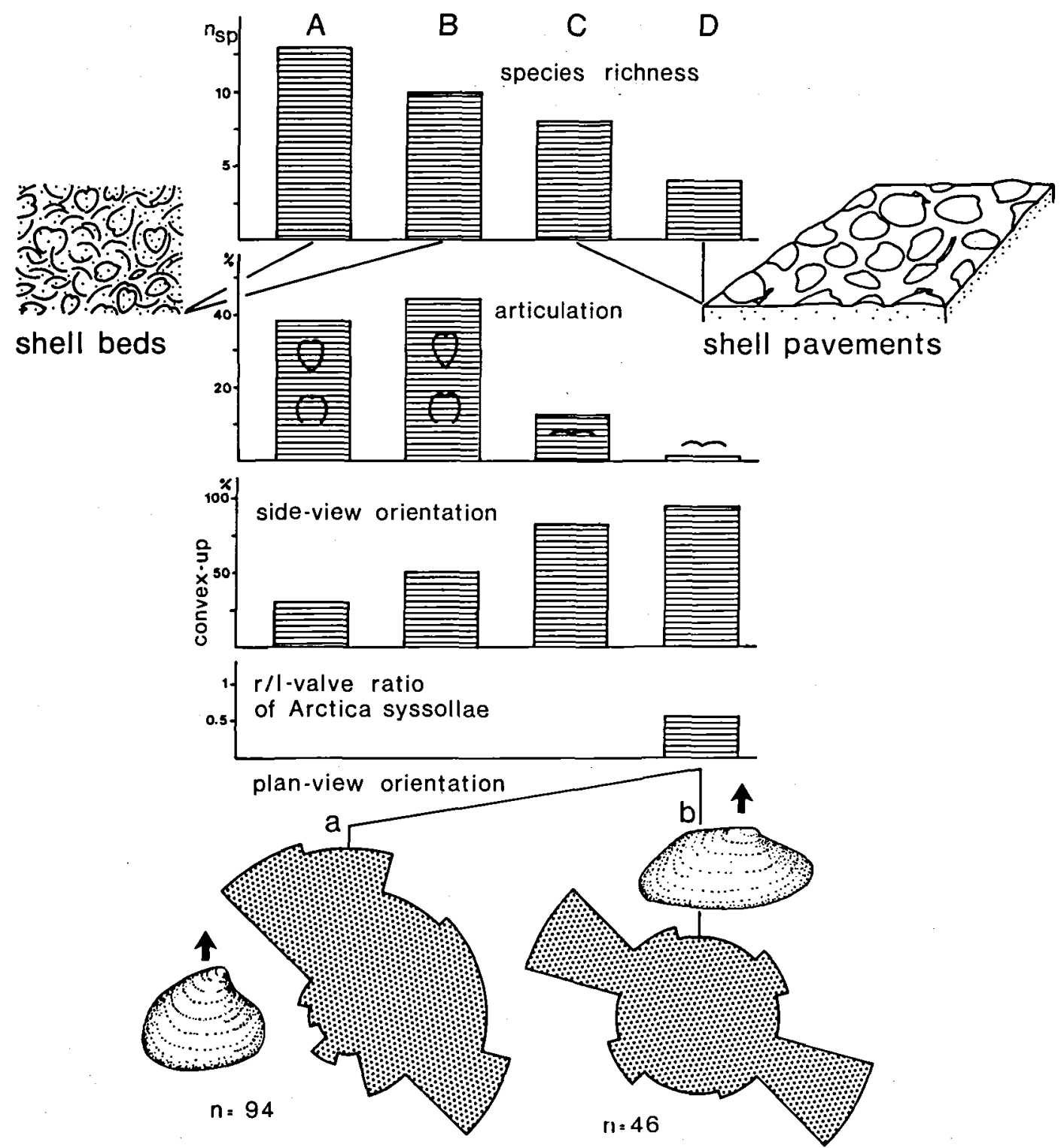

Fig. 20. Biostratinomic data of shell beds and shell pavements of the Lopatinia callomoni association which underwent various degrees of lateral transport. For further explanation see text. a. Arctica syssollae, b: Tancredia magna. Locality 3.

association described earlier on. Frequently, however, shell pavements occur on the foresets of large-scale crossbeds which exhibit pronounced influence of lateral transport (see samples $\mathrm{C}$ and $D$ in Fig. 20). Although the typical species of the L. callomoni association (A. syssollae, C. broenlundi and T. magna) are still present, overall diversity decreases; in particular, smaller and more delicate species are no longer present. This is clear evidence of sorting. Also indicative of sort- ing is the right/left valve ratio in sample $D$, measured in Arctica syssollae. The percentage of articulated shells is drastically lower than in samples A and B. The few specimens which are still articulated are strongly gaping, indicating that the ligament was still functioning when reworking took place. Whereas orientation in the parautochthonous shell beds is more or less random, the shell pavements exhibit a preferred orientation pattern with most shells in a con- 


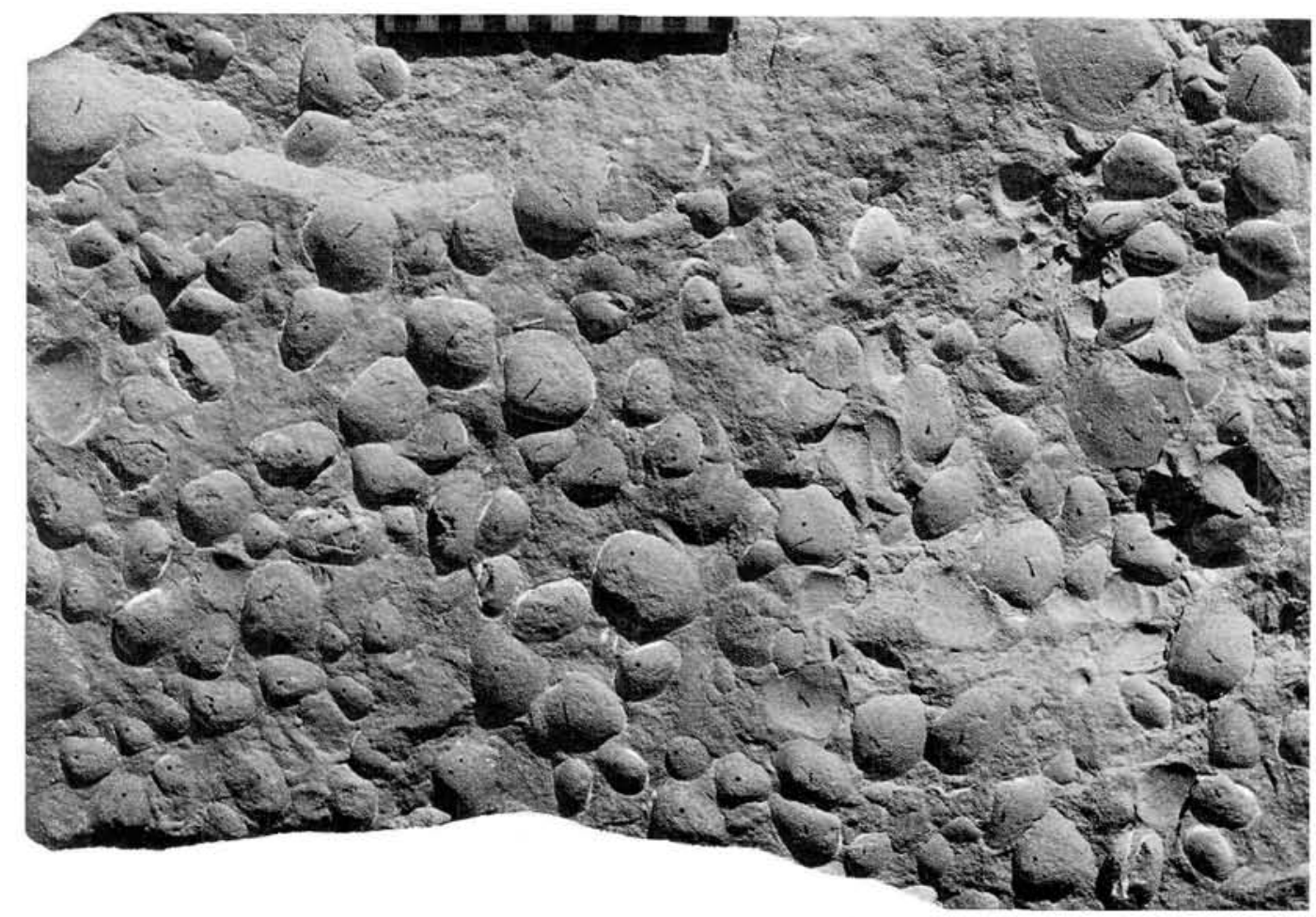

Fig. 21. Current transported shell pavement consisting mainly of Arctica syssollae and Lopatinia callomoni with some Camptonectes broenlundi. Bedding plane view. Scale in $\mathrm{cm}$. Locality 3 .

vex-up position (Fig. 21). Planview orientation is also present; the more circular $A$. syssollae shows a less pronounced preference than the elongate T. magna. In both cases orientation patterns are typical of current-generated shell pavements.

A similar relationship between shell beds and shell pavements is found at locality 5 , where species richness, evenness and degree of articulation decrease with the transition from shell beds to shell pavements. Again, this is clearly the result of increasing lateral transport combined with sorting (Fig. 22). Between shell beds and shell

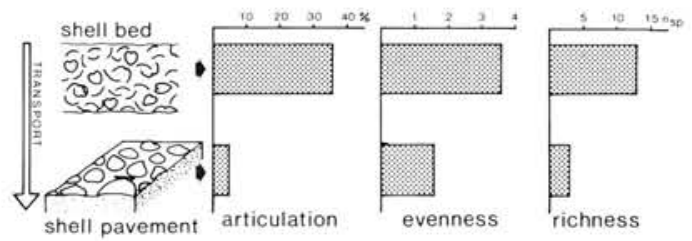

Fig. 22. Biostratinomic data of shell bed and shell pavement of in-situ reworked (shell bed) and current-reworked (shell pavement) Lopatinia callomoni association. Locality 5. pavements numerous transitions are found which exhibit features intermediate between the two extremes.

Finally, shell pavements derived of the $L$. callomoni association may show admixtures of faunal elements from other associations. This is particularly true of Ditrupa nodulosa, which may form 30 to 50 percent in terms of relative abundance.

Storm-generated shell beds of the Camptonectes broenlundi association.

Shell beds of the $C$. broenlundi association cannot be classified according to progressive stages of reworking and usually exhibit fairly uniform diversity values. In only two examples do admixtures of Ditrupa nodulosa occur and in each case represent 50 to $60 \%$ in terms of relative abundance. In these examples, the smaller and more delicate elements of the $C$. broenlundi association are missing, indicating some degree of sorting caused either by repeated in-situ reworking or 
else by some lateral transport. The latter is supported by the admixture of Ditrupa.

Whereas in most shell beds lateral transport of the elements of the $C$. broenlundi association cannot be demonstrated, there are nevertheless clear signs of in-situ reworking. At localities 25 and 26, shell beds up to $50 \mathrm{~cm}$ in thickness occur which exhibit a dense packing of shells. These shell beds are not the result of transport because there is no evidence of sorting and, above all, the side-view orientation of shells is not that of typical current-generated shell beds, which is preferredly convex-up. Instead, the majority of shells, particularly $C$. broenlundi, have oblique and vertical positions within the sediment (Figs 5 , 23). Imbrication of shells is quite common both in flat and concavo-convex valves of Camptonectes and these imbricated clusters are again commonly in a near vertical position. Vertical packing of shells is a relatively rare phenomenon. It has been described for example by Sanderson \& Donovan (1974), Grinnell (1974) and Greensmith \& Tucker $(1968,1969)$. In all these cases, the packing took place in intertidal areas either on beaches (Sanderson \& Donovan 1974), oyster shell bars (Grinnell 1974), intertidal bars (Greensmith \& Tucker 1968, 1969) or in narrow channels just below the low tide mark (Grinnell 1974) and was caused either by strong tidal currents or waves. For the initiation of the vertical packing obstacles such as rocks or a very uneven morphology seem to have been a prerequisite. In all cases sorting was pronounced.

In the Greenland examples, the development of vertical packing never reached the degree seen in the modern examples, and no sorting was observed to have taken place. The preservation of very thin-shelled faunal elements such as Praebuchia kirghisensis and the lack of abrasion on many shells furthermore exclude an origin by tidal currents or continuous wave influence. It is therefore suggested that these shell beds are the result of short-term events, that is storms, which caused shell bed formation by winnowing of the finer matrix (see also Salazar-Jimenez, Frey \& Howard 1982, for examples from the Recent). Brenner \& Davies (1973) described storm-generated shell beds from the Oxfordian of the Western Interior of the U.S. In none of their three types of shell beds does vertical imbrication occur, but a convex-up orientation clearly domi-

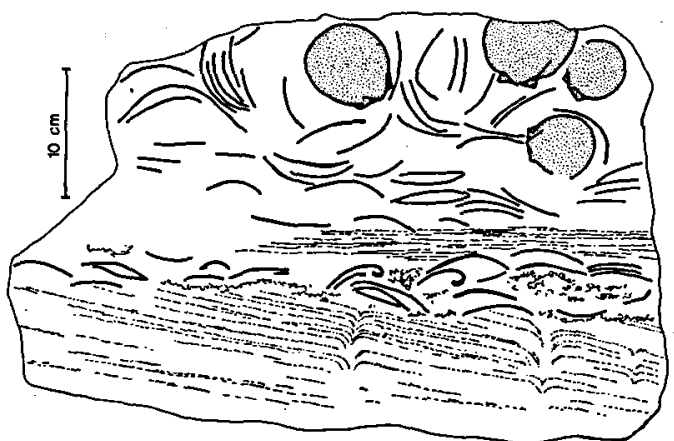

Fig. 23. Block of sandstone representing three depositional episodes. Lowermost part (episode 1), top of crossbed with escape burrows, probably produced as response to deposition of the overlying bed. Episode 2 started with the deposition of current-oriented Camptonectes shells, which became buried by parallel laminated sand.

At the top, part of a thick shell bed, representing episode 3, is seen. The base is formed by flat-lying Camptonectes shells, some of which are articulated. Owing to packing, no clear orientation pattern is developed. Near the top, Camptonectes shells are deposited both horizontally and vertically, indicating that the whole bed was deposited very rapidly. Locality 25 .

nates. Furthermore, except for their swell lag shell beds, an erosive base and graded bedding is present, both features unknown from the Milne Land examples. The lack of grading may be explained by the very well sorted sediment. Thus, an erosion surface may not be recognisable owing to the similarity in grain size below and above it. Of particular interest is the fact that Brenner \& Davies' swell lag shell beds consist of valves of approximately the same size of a large Camptonectes, similar in shape to the East Greenland form. According to them, complete Camptonectes shells are only concentrated in sediments deposited under low energy conditions, which was clearly not the case for the Aldinger Elv Member. It is suggested that the latter formed through short-term in-situ reworking combined with winnowing caused by storms and that renewed deposition of shells was rapid. Turbulent conditions rather than unidirectional currents seem to have prevailed during deposition, resulting in chaotic shell orientation with formation of imbricate shell nests. Fig. 24 shows some characteristic features of three consecutive shell beds which are thought to have formed in this way. 


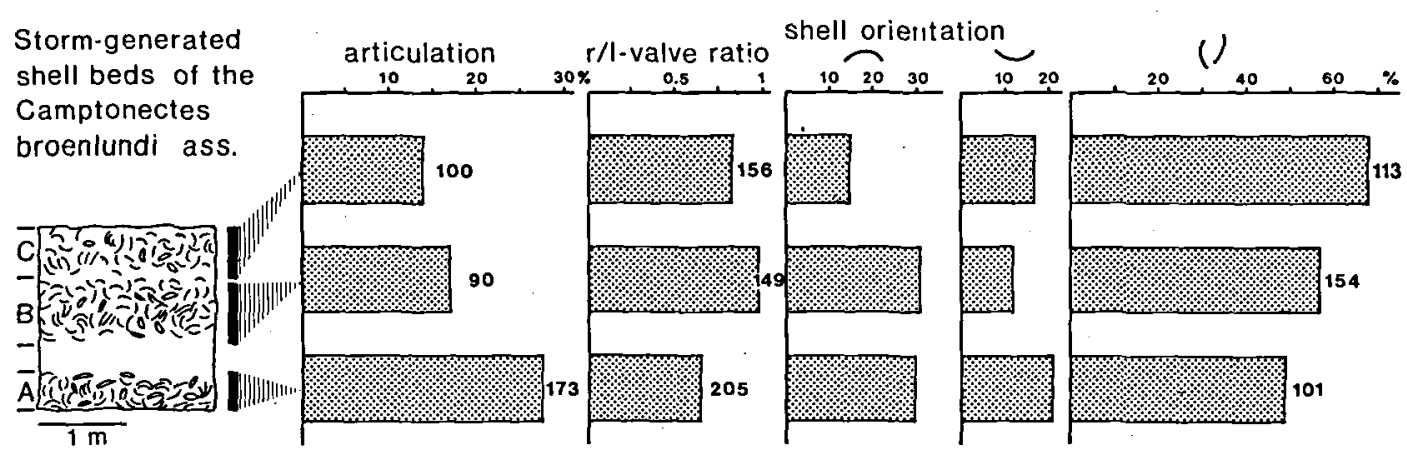

Fig. 24. Biostratinomic features of three storm-generated shell beds of the Camptonectes broenlundi association. Locality 26.

\section{Facies distribution within the sand body}

The combination of the lithological and biological parameters discussed above allows the recognition of 5 different facies (A-E) within the sandstone (Fig. 3). It can be demonstrated that this vertical zonation reflects a lateral zonation, in principle subparallel to the transgressive base of the wedge (Fig. 11).

The individual facies are as follows.

\section{Facies A.}

Fine- to medium-grained sandstone. Homogeneous with very few primary sedimentary structures. Bivalves rare, often in life position (e.g. Modiolus strajeskianus). Trace fossils abundant, Curvolithus ichnocoenosis.

\section{Facies B.}

Fine- and medium-grained sandstone. Parallel lamination, as well as small- and large-scale cross lamination. Bivalves abundant, often as dense convex-up shell pavements on isolated bedding planes. Packing of shells rare, and only in thin layers. $L$. callomoni association dominant, $C$. broenlundi and $D$, nodulosa associations rare. Planolites ichnocoenosis.

\section{Facies C.}

Up to one meter thick coquinas, dominated by Camptonectes, though many other species occur. Ammonites abundant. The shells occur sometimes as pavements, but most characteristic are vertically imbricated, densely packed Camptonectes. Trace fossils absent, also in the few large- scale cross-bedded and parallel laminated sandstone lenses which separate the coquinas.

\section{Facies D}

Well bedded fine grained sandstone with parallel lamination, small- and large-scale crossbedding, or homogeneous. Trace fossils scattered, $A n$ corichnus ichnocoenosis.

\section{Facies E}

Interbedded platy sandstone and shaley mudstone. Lenticular bedding, small-scale crossbedding and parallel lamination occur. Bivalves scattered, isolated or as shell pavements. The bivalve Aguilerella is relatively common. Trace fossils rare: Thalassinoides ichnocoenosis.

\section{Interpretation of the facies sequence}

The following interpretation is based on the previously mentioned assumption that the time lines cut the gradational lower boundary of the sand wedge while the upper sharp boundary is generally isochronous. The facies sequence consequently represents the facies variation across the original sand body surface. The offshore position of the sand, documented by the overall geological setting, together with the distinct zonation across the sand body, strongly favours the hypothesis of an offshore shoal (Fig. 25). The topography associated with such a feature is likely to produce a bottom zonation related to the degree of exposure to waves and currents. Following the procedure of Brenner (1978) the empirical data is seen in the framework of this hypothesis.

Facies A, which comprises the easternmost 


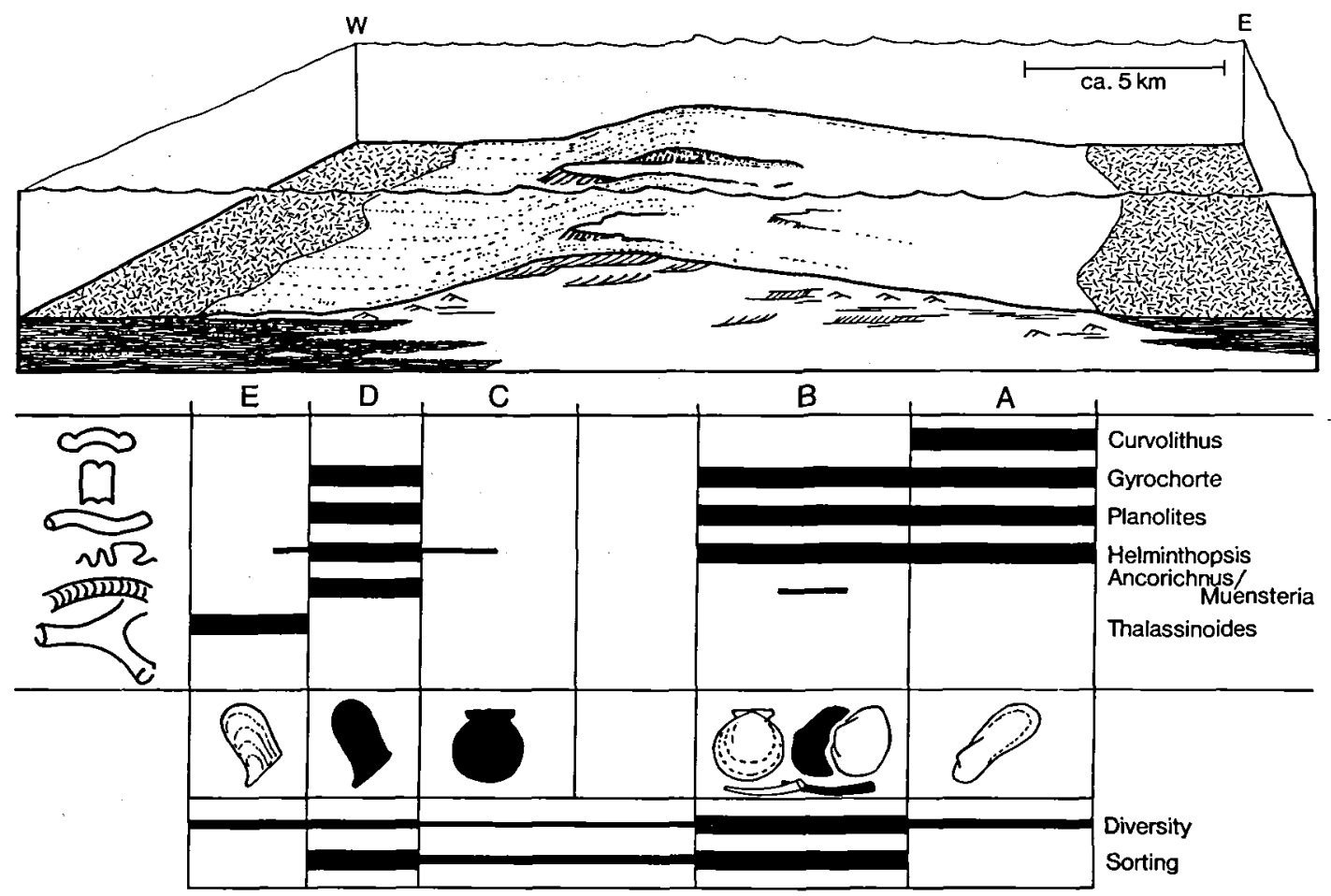

Fig. 25. Reconstruction of the sand complex in Late Oxfordian time. Note crest of shoal dissected and sheet sands brought into the back bar area by storms. The distribution of trace and body fossils is schematic. Symbols as in Fig. 3. Black symbols indicate reworking. Diversity refers to autochthonous associations.

part of the preserved sand complex, is believed to represent the somewhat deeper, ocean-facing part of the shoal. The high degree of bioturbation (absence of primary sedimentary structures) supports this view as does the ichnofauna (Curvolithus ichnocoenosis). On Jameson Land the Curvolithus ichnocoenosis shifts seawards into the fine-sandy mudstones of the Fossilbjerget Member. Similarly, on Milne Land, the Curvolithus ichnocoenosis is believed to give way seawards to muddy deposits, in this case the Hare Elv Formation or its equivalent (Fig. 26).

Landwards, facies A gives way to facies B as the higher parts, possibly the crestal zone of the shoal, is approached. Shell beds dominated by burrowing, partly siphonate bivalves, channelling and large-scale crossbedding indicate a higher energy level in facies B where erosion, sand transport and fairly frequent reworking played an important role. Consequently, bioturbation is only rarely preserved.

Ichnologically the change is defined by the dis- appearance of Curvolithus, whose producer apparently depended on a fairly stable substrate without too frequent reworking.

The shoal crest proper is not believed to be represented by the deposits actually encountered. The preservational potential of that part of the sand complex was probably very low, compared to that of the flanks. Accordingly, facies $\mathbf{C}$ is interpreted to represent the lee side deposits of the shoal, subject mainly to storm generated influx of sand eroded from the crest and seaward side of the shoal and shells largely reworked in situ. The peculiar packing of Camptonectes supports this view. Randomly or mainly vertically packed Camptonectes shells exhibiting very little wear strongly indicate rapid sedimentation of a sand and shell mixture, consisting of dead and living bivalves. In these cases, erosion of the shoal must have been considerable judging from the size of the 'coquinoid spillover fans'.

The sandstones and coquinas of facies $\mathrm{C}$ gradually change into the sheet sandstones of 

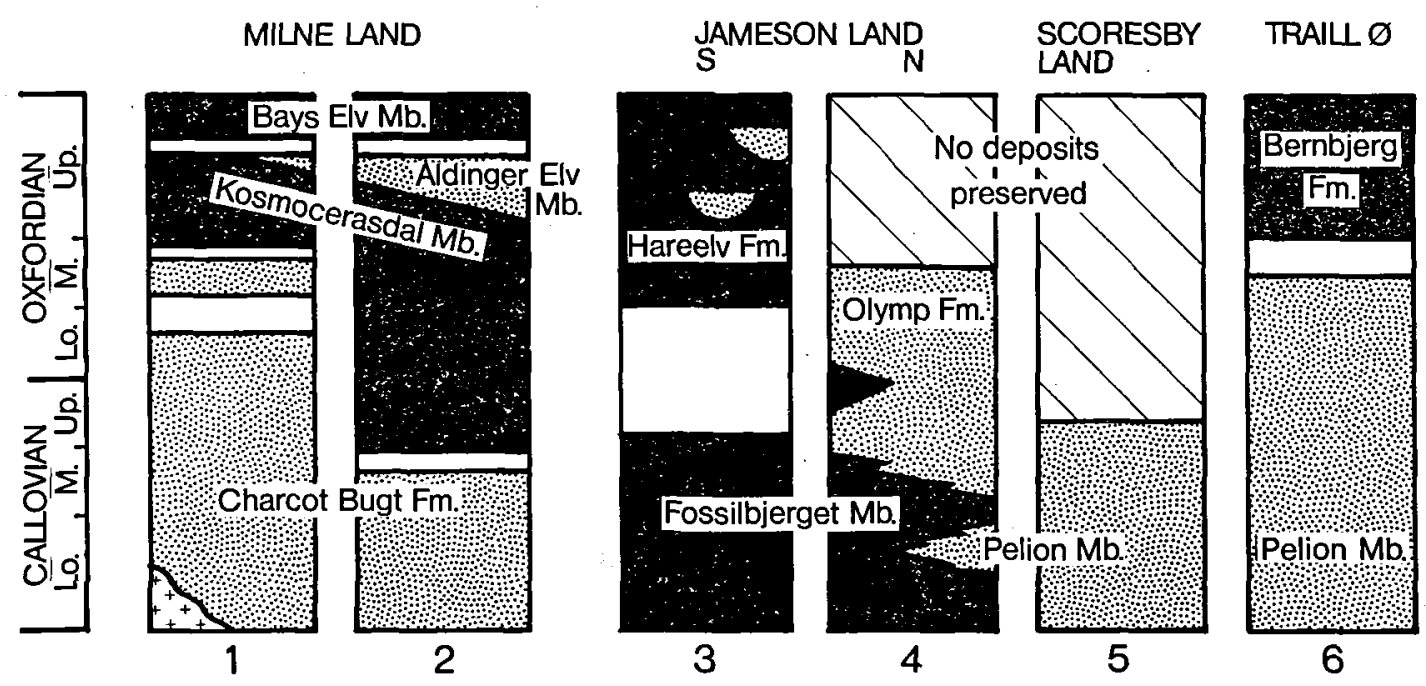

Fig. 26. Generalized stratigraphical framework of the Jameson Land basin. For position of the individual section see Fig. 1. Data from Håkansson et al. 1971, Surlyk 1977 and Callomon \& Birkelund 1980. Note the wedge shape of the Aldinger Elv Member, and the relation between the basement and the onlapping Charcot Bugt Formation.

facies D. In the proximal part this facies is characterized by fine sand, while the more distal parts exhibit alternations of mudstones from the 'lagoon' behind the shoal and sheet sands washed into the back bar area from the shoal. The sands thus accumulated in the low energy environment of the lee side of the shoal. Apart from the sand brought in by storms, silt and very fine sand constitute the equilibrium deposits. In addition to the fine sediments, organic detritus must have also settled judging by the presence of the $A n$ corichnus ichnocoenosis.

Further into the back bar area Thalassinoides replaced Ancorichnus. Apart from the trace fossil producer the fragile epibyssate bivalve Aguilerella dwelled here, probably living in a vertical position like the Recent Isognomon isognomon (Yonge 1968). Ichnological and sedimentological evidence suggests the lowest degree of agitation of the shoal complex.

\section{Palaeogeographical evolution}

The Aldinger Elv sandstone was deposited near the eastern margin of the Jameson Land Basin. In the northern reaches of this basin, the Jurassic seas tended to shallow or even close at times, while in the southern and deeper part there was a continuous connection with the incipient Atlantic Ocean. Evidence of the position of the western margin of the Jameson Land sea are found on Milne Land, where the coarse sandstones and conglomerates of the Charcot Bugt Formation directly overlie the high relief Caledonian basement. A single root horizon documents the proximity of the shore, while scattered ammonites, corals and trace fossils (Håkansson et al. 1971) demonstrate that the sandstone is predominantly marine (e.g. Callomon \& Birkelund 1980).

The central and northern parts of the Jameson Land Basin are represented by coarse- to medium-grained sandstones (Pelion Member) (Fig. 26). These sands date back to the basal Bathonian, while the Charcot Bugt sandstones and conglomerates are no older than Upper Bathonian, the time of the transgression of the Milne Land area. Southwards, the Pelion sandstone interfingers with the marine mudstones of the Fossilbjerget Member.

The sandstones of the Pelion Member represent two major ichnocoenoses; a northern one characterized by Ophiomorpha, and a southern, somewhat deeper one, characterized by Curvolithus (Birkelund \& Heinberg, 1974). This general picture persists through the Callovian (Fig. 27a) and into the Oxfordian, during which time the Charcot Bugt sandstone became re- 
stricted to the western part of the Milne Land area and gave way eastwards to the mudstones of the Kosmocerasdal Member (Middle Oxfordian, densiplicatum zone) (Fig. 27b). The westward onlap of the Charcot Bugt sandstone on the Caledonian basement reflects continued transgression.

In Late Oxfordian (and Kimmeridgian) times (Fig. 27c) the transgression on Milne Land reached its peak. The Charcot Bugt sandstone is replaced by silty and sandy mudstones (Bays Elv Member). The sediments of the Milne Land area are exclusively mudstones, with the exception of the Aldinger Elv sandstone wedge which separates the mudstones of the Kosmocerasdal and Bays Elv Members.

The westerly wedging out of this sandstone indicates that it was deposited as an offshore sand, separated from the coast, at least in the Milne Land area, by a wide zone of muddy sediments. This offshore position raises the question as to the source of the sand, as well as to the depositional environment of the sand body.

Shallowing over the rising crest of a specific
Milne Land fault block (Surlyk 1978, Callomon \& Birkelund 1980) may have been responsible for the existence of the sand. This would be in close analogy to the situation, during the Oxfordian, of the Wollaston Forland area further to the north, as inferred by Sykes \& Surlyk (1976 fig. 9).

Offshore sands are often interpreted as relics of former shallower depositional environments which were reworked during transgression (e.g. Howard \& Reineck 1972). However, this explanation is not plausible in the case of the Aldinger Elv sandstone. A thickness of $90 \mathrm{~m}$ of sand, laterally giving way to mud, cannot be regarded as a relic. There must have been a continuous influx of sand to keep pace with the sedimentation of the Kosmocerasdal muds.

The relatively fine grain size of the sand and the high degree of sorting suggests that the source area was quite distant, in contrast to all known littoral deposits from the Jurassic of East Greenland which are rather coarse-grained and interpreted to reflect a high relief of the hinterland.

The palaeogeographical reconstruction of the
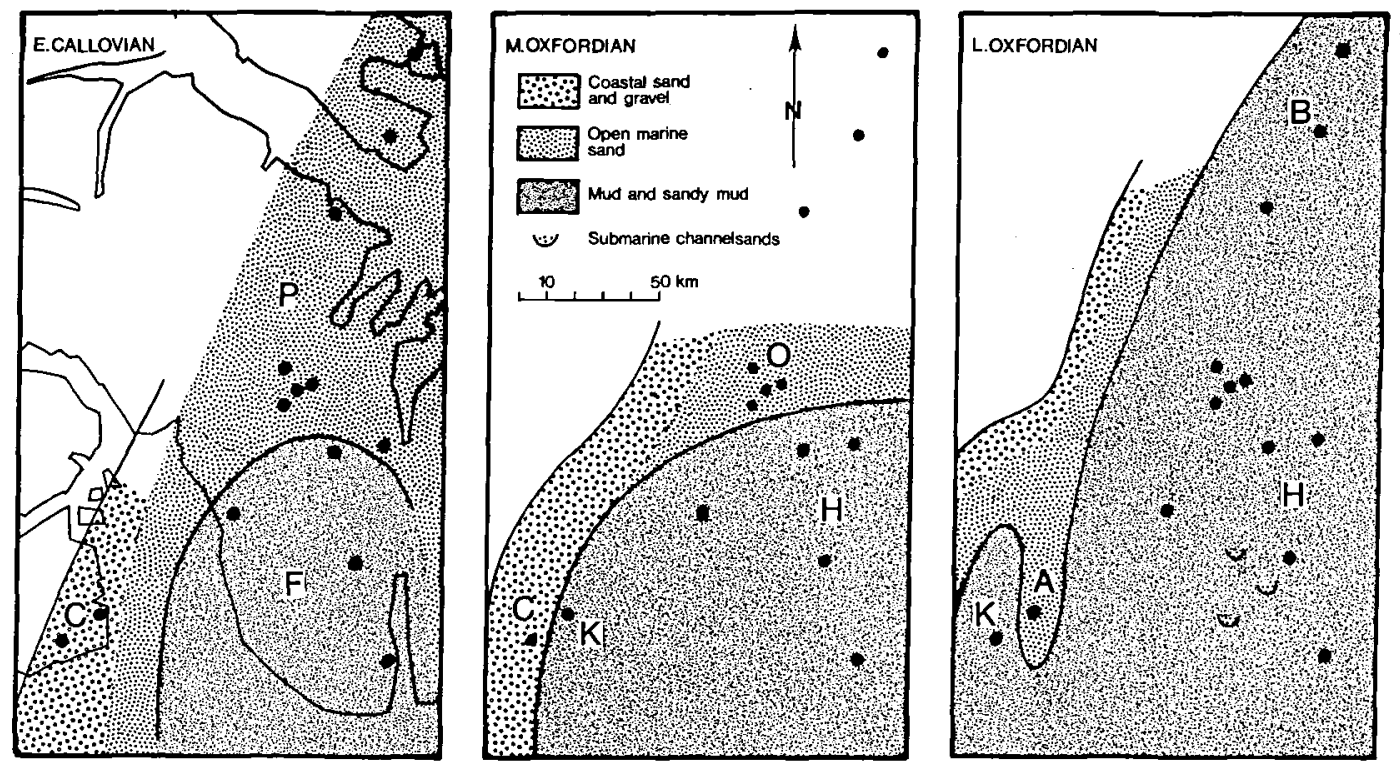

Fig. 27. Palaeogeographical maps of the Jameson Land region during Early Callovian to Late Oxfordian times (see also Surlyk 1977). The black dots are the localities shown also in Fig. 1. Capital letters indicate major exposures of the following formations and members (see also Fig. 26.): Aldinger Elv Member (A), well sorted fine- to medium-grained sandstones. Bern Bjerg Formation (B), marine mudstone. Charcot Bugt Formation (C), continental and marine coarse-grained sandstones and conglomerates. Fossilbjerget Member $(F)$, marine sandy mudstone. Hareelv Formation $(H)$, marine mudstone with large channel sands. Olympen Formation $(O)$, well sorted marine sandstone. Pelion Member (P), well sorted fine- to coarse-grained marine sandstone. Kosmocerasdal Member (K), marine sandy mudstone.

Note the eastward deflection of the sand-mud boundary prior to the formation of the Aldinger Elv sandstone shoal in the Late Oxfordian. 


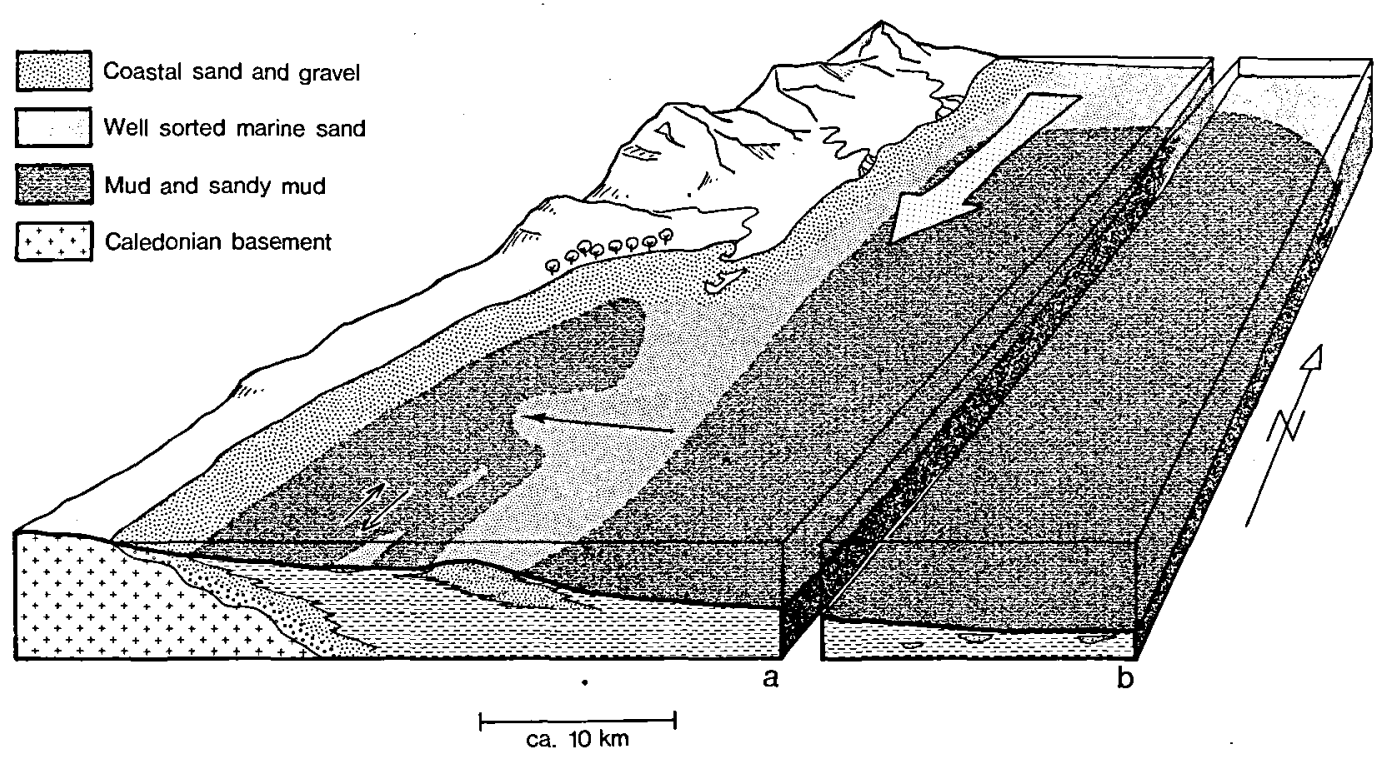

Fig. 28. Reconstruction of the western (a) and central (b) part of the Jameson Land sedimentary basin in the Late Oxfordian. The base of the blocks represent Middle Oxfordian.

The situation on Milne Land (a) is characterised by the offshore shoal of the Aldinger Elv sandstone. The protected marine muds on the west side of the shoal represent the Kosmocerasdal mudstone, while the coastal sands and gravels are the probably Upper Oxfordian extension of the Callovian-Middle Oxfordian Charcot Bugt sandstone. The main sand transport is from the north by longshore currents and wave action. Part of the sand is transported offshore along the axes of the shoal. Occasionally, storms winnowed sand from the crest to the lee side of the shoal, where it settled as sheets on the backshoal mud. Tidal currents may then have contributed to spreading the sand. The backshoal mud has a relatively high content of fine sand, while the offshore mud, represented by the Hareelv Formation on Jameson Land (b) is somewhat finer.

Jameson Land region for the Middle and Late Jurassic suggests the following explanation for the origin of the sandstones of the Aldinger Elv Member: The sand came from the north, transported along the coast by longshore, possibly tidally influenced currents and waves. Towards the south the sands were transported away from the coast, which trended in a southwesterly direction, and out into the basin along a shoal or barrier system (Fig. 28).

The continued offshore accumulation of sand completely depended on the sea floor topography. Most of the shoal was separated from the shore by a protected, quiet water marine environment which prevented any direct influx of sand-sized sediment from the coast into the offshore area.

The shoal thus acted both as a link between the offshore sand and the source area, and as a site of offshore sand deposition.

These two functions were causally connected in an irreversible manner, whereby sediment transport and sediment accumulation were closely interdependent. Detachment of the shoal from the shore, or a break in sediment influx, would have terminated the history of the offshore sand. Muddy shelf sedimentation would have taken over immediately and continued as the transgression proceeded.

The depositional regime on and around the shoal varied, depending on weather conditions and location on the shoal. During fair weather, sand was driven along the shoal by longshore, possible tidally influenced currents. Muddy sediments were deposited in the back bar area.

During storms the shoal, and especially the crest, was subject to winnowing with an occasional transport of sand into the swale. The finer material was carried landwards in suspension, while the coarser particles were moved along the bottom, in places probably as spillover fans from the shoal crest. The formation of extensive coquinas with large vertically packed Camptonectes is related to the proximal and 
thicker parts of such rapidly deposited fans. The thinner and more distal part of the fans formed wide sheet sands, which after deposition were submitted to reworking and transport, occasionally as migrating sand ripples on top of the semiconsolidated back-bar muds.

The dominance of westerly transport directions in the entire area (Fig. 1) probably reflects the storm-generated landward transport of sand.

Such deposits represent extreme energy conditions, and they are unlikely to be reworked, at least completely, during subsequent normal weather periods. Their preservational potential is therefore high.

The associated N-S bimodal transport pattern found in the western part of the area (facies C-E) may reflect the reinforced activity of tides partly locked in the bay behind the shoal.

A somewhat similar analogy may be found in the northern part of the "Jameson Land sea" during Bathonian-Callovian times (Surlyk 1977: fig. 39).

In this particular case, sand sheets occasionally transgressed onto muddy sediments, producing interbedded sandstone/mudstone with parallel and lenticular bedding, which is also characteristic of the lower boundary of the Aldinger Elv sandstone.

In contrast, the sharp upper boundary of the Aldinger Elv sandstone is a result of the restricted and isolated position of the area of sand accumulation, and of the continued rise of sea level in the late Oxfordian.

The topographic high, represented by the shoal, was essential for the transport of coarse clastic material into a generally muddy, low energy environment. But once below the depth of continuous sand transport, a sudden shift in sedimentation resulted. The shoal then turned into a relic sand body, and became covered by muddy deposits in hydrodynamic equilibrium with the new energy conditions. In the absence of the shoal, the continued longshore transport of sand shifted to a new position nearer to the land.

Detachment of the shoal at its proximal end (Duane et al. 1972) could have had a similar effect. As the supply of sand was cut, the shoal was prevented from keeping pace with the rise of the sea. Extreme energy conditions would then have caused a levelling of the detached shoal, since no additonal coarse clastic material was available.
Muddy sedimentation would have taken over, reinforced by the continued transgression.

In either case, the shift in sedimentation was a sudden one, related to the presence or absence of the shoal, and not to a gradual decrease in influx of sand.

\section{Offshore shelf sands: comparison and summary}

The Cretaceous of the Western Interior of the United States provides a number of examples of elongate sand complexes (Johnson 1978:246), in particular the Upper Cretaceous Sussex Sandstone (Brenner 1978), Shannon Sandstone (Spearing 1975), Eagle Sandstone (Shelton 1965) and Gallup Sandstone (Sabins 1963). These are all hydrocarbon producing stratigraphic traps, where the sandbody is separated from coastal sandy deposits by a wide zone of mud.

The closest analogies to the Aldinger Elv Sandstone are probably the bar complexes topping the Eagle Sandstone and the Gallup Sandstone.

The former was deposited as an offshore barrier, some $60 \mathrm{~km}$ long, $40 \mathrm{~km}$ wide and $30 \mathrm{~m}$ thick. These dimensions are somewhat larger horizontally than those of the Aldinger Elv Sandstone, while the thickness is considerably less.

In the case of the Gallup Sandstone, the bar complex consists of a series of facies, similar to those on Milne Land (Sabins 1963). These are beach sand, back bar mud, bar sand and fore bar mud. The complex itself consists of three bars, the largest of which is about $50 \mathrm{~km}$ long, $3 \mathrm{~km}$ wide and $13 \mathrm{~m}$ thick, again much thinner than the Aldinger Elv Sandstone. This difference may be explained by the transgressive nature of the $\mathrm{Al}-$ dinger Elv Sandstone, where continued sedimentation kept pace with a rise in sea level, whereas the Western Interior bars were formed under regressive conditions. A gradual change from bar sand to the underlying mud, while the upper boundaries are sharp, is another anlogy to the Aldinger Elv Sandstone. The two remaining Cretaceous linear sandstones, the Shannon Sandstone and the Sussex Sandstone differ from the Aldinger Elv Sandstone in their genesis, de- 
spite superficial similarity in shape. They are not single hydrodynamic entitites, but represent the deposits of sand moved as multible discrete bodies (Spearing 1975) or as a migrating sandy sheet (Brenner 1978). The flat base and the convex top of these two sandstones represent a further distinguishing character.

A last example, from the Oxfordian Sundance Formation of the Western Interior (Brenner \& Davies 1974), does not resemble the Aldinger Elv Sandstone structurally. However, many of the facies associations connected with individual sand bars correspond to the Aldinger Elv Sandstone, such as the storm lag coquinas, the distal storm layers in the muddy interbar areas and the coarsening upwards sequences of the individual bars.

To contrast these difference examples of ancient elongate sand bodies, the main characteristics of the Aldinger Elv Sandstone can be summarized as follows:

(1) The Aldinger Elv sandstone is $90 \mathrm{~m}$ thick. This is more than other ancient counterparts, and it is more than the topographic height of any known modern offshore sand body (Johnson 1978).

(2) It was a single sandstone unit. No intraformational shales occur, which could indicate a composite origin of the sand body.

(3) It was formed as a hydrodynamic entity. The lateral zonation documents the presence of a lee side and a stoss side, corresponding to the degree of wave and current action from the ocean.

(4) It was a permanent and stationary structure. On grounds of the interfingering of sandstone and mudstone, together with the considerable thickness of the former, one has to postulate a constant influx of sand along a shoal, as opposed to a discrete migrating sand body.

In these characters, the Aldinger Elv sandstone seems to be an almost unique case of a shore-connected offshore sandy shoal with the bar complex of the Gallup Sandstone as the closest analogue. Genetically it differs from ancient examples of composite offshore sands, as well as from modern examples of migrating sand ridges (Houbolt 1968, Swift 1974) both with respect to sedimentology and tectonic framework.

\section{Conclusions}

The Aldinger Elv Member of Milne Land represents a shallow water offshore sand body intercalated between muddy sediments. It consists of numerous superimposed sand sheets which formed an elongate shoal trending in a northsouth direction. The sediment was supplied from the north where coastal sands were transported by longshore currents southwards into the sea while the coast line migrated towards the southwest.

With the help of sedimentological, biostratinomic and palaeoecological data a distinct zonation parallel to the long axis of the sand shoal can be recognised. Authochthonous associations characterized by Modiolus, Lopatinia and Camptonectes respectively are found on the seaward-facing side of the shoal. Together with a trophically diverse trace fossil fauna they indicate a relatively low energy environment and stable substrates, disturbed occasionally by deepreaching storms. In the central part of the shoal, sedimentary structures and the dominance of transported assemblages indicate a high energy regime. Shell beds and shell pavements illustrate successive stages of destruction of original benthic communities by lateral transport. The low degree of bioturbation reflects shifting substrates and high sedimentation rates.

On the shore-facing side of the shoal, shell beds with vertically imbricated Camptonectes shells were formed by heavy storms in shallow water. Towards the shore, the shoal interfingers with highly bioturbated back-bar muds. The trace fossils and rare epibyssate bivalves found in life position characterize a low energy environment.

\section{Dansk sammendrag}

Aldinger Elv Member (Øvre Oxfordian) på Milne Land (Øst Grønland) er et kileformet sandstenslegeme, indlejret mellem to skifrige mudderstens sekvenser. Mod øst er sandstenen ca. $90 \mathrm{~m}$ tyk. Vestpå bliver den gradvist tyndere, indtil den forsvinder helt.

På grundlag af paleontologiske, sedimentologiske og ichnologiske observationer er der foretaget en rekonstruktion af det oprindelige aflejringsmiljø, dets udvikling, morfologi og de paleogeografiske forhold. Der er tale om en sandbarriere som var adskilt fra kysten ved en bred laguneagtig lavning, med fortrinsvis siltede sedimenter. Barrieren var $i$ sin ene ende (den nordlige) i direkte forbindelse med den oprindelige kyst, således at sand til stadighed kunne transporteres ud $\mathrm{i}$ bassinet, langs barrierens ryg. 
De sedimentære strukturer, bioturbationen og fordelingen af makrofossiler (hovedsageligt muslinger) viser en tydelig zonation på tvars af barrieren. Zoneringen kan relateres til forskelle $i$ energiniveau hen over barrieren.

Acknowledgements. The authors would like to thank M. Leckie, Boulder, and J. E. Warme, Golden, for critically reading the manuscript and making helpful suggestions. R. Bromley kindly read the manuscript and offered helpful criticism. The Geological Survey of Greenland is thanked for permission to publish this paper.

\section{References}

Aldinger, H. 1935: Geologische Beobachtungen im oberen Jura des Scoresbysundes (Ostgrønland). Meddr Grønland $99,1,128 \mathrm{pp}$.

Berg, R. R. 1975: Depositional environment of Upper Cretaceous Sussex Sandstone, House Creek Field, Wyoming. Bull. Am. Ass. Petrol. Geol. 59, 2099-2110.

Birkelund, T. \& Heinberg, C. 1974: Facies variation and trace fossil assemblages of the Vardekloft and Olympen Formations of Jameson Land and Scoresby Land, central East Greenland. Rapp. Gronlands geol. Unders. 75, 100-103.

Brenner, R. L. 1978: Sussex Sandstone of Wyoming-Example of Cretaceous Offshore Sedimentation. Bull. Am. Ass. Petrol. Geol. 62, 181-200.

Brenner, R. L. \& Davies, D. K. 1973: Storm-generated coquinoid sandstone: genesis of high energy marine sedjments from the Upper Jurassic of Wyoming and Montana. Bull. geol. Soc. Am. 84, 1685-1698.

Brenner, R. L. \& Davies, D. K. 1974: Oxfordian sedimentation in Western Interior United States. Bull. Am. Ass. Petrol. Geol. 58, 407-428.

Bromley, R. G. \& Asgaard, U. 1972: Notes on Greenland trace fossils. Rapp. Grønlands geol. Unders. $49,30 \mathrm{pp}$.

Callomon, J. H. 1961: The Jurassic system in East Greenland. In Raasch, G. O. (edit.) Geology of the Arctic 1, 258-268. Toronto U.P.

Callomon, J. H. \& Birkelund, T. 1980: The Jurassic transgression and the mid-late Jurassic succession in Milne Land, central East Greenland. Geol. Mag. 117, 211-226.

Clifton, H. E. \& Thompson, J. K. 1978: Macaronichnus segregatis: a feeding structure of shallow marine polychaetes. J. sed. Petrol. 48, 1293-1302.

Duane, D. B., Field, M. E., Meisburger, E. P., Swift, D. J. P. \& Williams, S. J. 1972: Linear Shoals on the Atlantic Inner Continental Shelf, Florida to Long Island. In Swift, D. J. P., Duane, D. B. \& Pilkey, O. K. (eds.) Shelf Sediment Transport: Process and Pattern, 447-498. Dowden, Hutchinson \& Ross.

Dörjes, J. 1972: Georgia coastal region, Sapelo Island, U.S.A.: Sedimentology and biology. VII. Distribution and zonation of macrobenthic animals. Senckenbergiana Marit. 4, 183-216.

Dörjes, J. \& Hertweck. G. 1975: Recent biocoenoses and ichnocoenoeses in shallow-water marine environments. In Frey, R. W. (edit.) The study of trace fossils, 459-491. Springer, New York.

Fürsich, F. T. 1974: Corallian (Upper Jurassic) trace fossils from England and Normandy. Stutgarter Beitr. Naturk., Ser. B, 13, 52 pp.

Fürsich, F. T. 1982: Upper Jurassic bivalves from Milne Land, East Greenland. Bull. Grønlands geol. Unders. 144, 126 pp.
Fürsich, F. T. \& Kennedy, W. J. 1975: Kirklandia texana Caster - Cretaceous hydrozoan medusoid or trace fossil chimaera? Palaeontology 18, 665-679.

Greensmith, J. T. \& Tucker, E. V. 1968: Imbricate structure in Essex offshore shell banks. Nature 220, 1115-1116.

Greensmith, J. T. \& Tucker, E. V. 1969: The origin of Holocene shell deposits in the chenier plain facies of Essex (Great Britain). Mar. Geol. 7, 403-425.

Grinnell, R. S., Jr. 1974: Vertical orientation of shells on some Florida oyster reefs. J. sediment. Petrol. 44, 116-122.

Håkansson, E., Birkelund, T., Heinberg, C. \& Willumsen, P. 1971: Preliminary results of mapping the Upper Jurassic and Lower Cretaceous sediments of Milne Land. Rapp. Gronlands Geol. Unders. 37, 32-41.

Heinberg, C. 1970: Some Jurassic trace fossils from Jameson Land (East Greenland). In crimes, T. P. \& Harper, J. C. (eds) Trace fossils. Geol. J. Spec. Issue 3, 227-234.

Heinberg, C. 1973: The internal structure of the trace fossils Gyrochorte and Curvolithus. Lethaia 6, 227-238.

Heinberg, C. 1974: A dynamic model for a meniscus filled tunnel (Ancorichnus $\mathrm{n}$. ichnogen.) from the Jurassic Pecten Sandstone of Milne Land, East Greenland. Rapp. Gronlands geol. Unders. $62,20 \mathrm{pp}$.

Heinberg, C. \& Birkelund, T. 1984: Trace Fossil Assemblages and Basin Evolution of the Vardekløft Formation (Middle Jurassic, central East Greenland). J. Palaeontol. In press.

Hertweck, G. 1972: Georgia coastal region, Sapelo Island, U.S.A.: Sedimentology and biology. V. Distribution and environmental significance of lebensspuren and in-situ skeletal remains. Senckenbergiana Marit. 5, 179-197.

Hertweck, G. 1973: Der Golf von Gaeta (Tyrrhenisches Meer) VI. Lebensspuren einiger Bodenbewohner und Ichnofaciesbereiche. Senckenbergiana Marit. 5, 179-197.

Howard, J. D. 1975: The sedimentological significance of trace fossils. In Frey, R. W. (edit.) The Study of Trace fossils. 131-146. Springer-Verlag New York.

Howard, J. D. \& Reineck, H. E. 1972: Physical and biogenic sedimentary structures of the nearshore shelf. Senckenbergiana Marit. 4, 81-123.

Houbolt, J. J. H. C. 1968: Recent sediments in the southern bight of the North Sea. Geol. Mijnbouw 47, 245-273.

Johnson, H. D. 1978: Shallow siliciclastic seas. In Reading, H. G. (edit.) Sedimentary environments and facies, 207-258 Blackwell, Oxford.

Ksiazkiewicz, M. 1970: Observations in the ichnofauna of the Polish Carpathians. In Crimes, T. P. \& Harper, J. C. (eds) Trace fossils. Geol. J. Spec. Issue 3, 283-322.

MacArthur, R, H. 1972: Geographical ecology. 269 pp. Harper \& Row, New York.

Nagle, J. S. 1967: Wave and current orientation of shells. J. sed. Petrol. 37, 1125-2238.

Pemberton, S. G. and Frey, R. W. 1982: Trace fossil nomenclature and the Planolites-Palaeophycus dilemma. $J$. Paleontol. 56: 843-881.

Reineck, H. E., Dörjes, J., Gadow, S. \& Hertweck, G. 1968: Sedimentologie, Faunenzonierung und Faziesabfolge vor der Ostküste der inneren Deutschen Bucht. Senckenbergiana lethaea 49, 261-309.

Röder, H. 1971: Gangsysteme von Paraonis fulgens Levinsen 1883 (Polychaeta) in ökologischer, ethologischer und aktuopaläontologischer Sicht. Senckenbergiana Marit. 3, 3-51.

Sabins, F. F., Jr. 1963: Anatomy of Stratigraphic Trap, Bisti Field, New Mexico. Bull. Am. Ass. Petrol. Geol. 47, 193-228.

Salazar-Jimenez, A., Frey, R. W. \& Howard, J. D. 1982: Concavity orientations of bivalve shells in estuarine and nearshore shelf sediments, Georgia. J. sed. Petrol. 52, $565-586$. 
Saleuddin, A. S. M. 1964: Observations on the habit and functional anatomy of Cyprina islandica (L.). Proc. Malac. Soc. Lond. 36, 149-162.

Sanders, H. L. 1968: Marine benthic diversity: a comparative study. Am. Nat. 102, 243-282.

Sanderson, D. J. \& Donovan, R. N. 1974: The vertical packing of shells and stones on some recent beaches. J. sed. Petrol. 44, 680-688.

Schäfer, W. 1962: Aktuo-Paläontologie nach Studien in der Nordsee. 666 pp. Waldemar Kramer, Frankfurt.

Seilacher, A. 1977: Evolution of trace fossil communities. In Hallam, A. (edit.) Patterns of evolution, 359-376. Elsevier, Amsterdam.

Shelton, J. W. 1965: Trend and genesis of lowermost sandstone unit of Eagle Sandstone at Billings, Montana. Bull. Am. Ass. Petrol. Geol. 46, 1385-1397.

Spearing, D. R. 1975: Shallow marine sands. In Depositional environments as interpreted from primary sedimentary structures and stratification sequences. Soc. Econ. Paleont. Miner. Short Course 2, 103-132.

Surlyk, F. 1977: Stratigraphy, tectonics and palaeogeography of the Jurassic sediments of the areas north of Kong Oscars Fjord, East Greenland. Bull. Gronlands geol. Unders. 123, $56 \mathrm{pp}$.

Surlyk, F. 1978: Jurassic basin evolution of East Greenland. Nature 274, 130-133.

Surlyk, F., Callomon, J. H., Bromley, R. G. \& Birkelund, T. 1973: Stratigraphy of the Jurassic-Lower Cretaceous sediments of Jameson Land and Scoresby Land, East Greenland. Bull. Grønlands geol. Unders. 105, 76 pp.

Swift, D. J. P. 1974: Continental shelf sedimentation. In Burk, C. A. \& Drake, C. L. (eds.) The geology of continental margins, 117-135. Springer-Verlag, Berlin.

Sykes, R. M. \& Callomon, J. H. 1979: The Amoeboceras zonation of the Boreal Upper Oxfordian. Palaeontology 22, 839-903.

Sykes, R. M. \& Surlyk, F. 1976: A revised ammonite zonation of the Boreal Oxfordian and its application in northeast Greenland. Lethaia 9, 421-436.

Taylor, J. 1978: Cenozoic. In McKerrow, W. S. (edit.) The ecology of fossils, 323-351. Duckworth, London.

Weiss, W. 1940: Beobachtungen an Zopfplatten. Z. Deutsch. Geol. Ges. 93, 333-349.

Weiss, W. 1941: Die Entstheung der 'Zöpfe' im Schwarzen und Braunen Jura. Natur $u$. Volk 71, 179-184.

Wilson, J. B. 1976: Attachment of the coral Caryophyllia smithi S. \& B. to tubes of the polychaete Ditrupa arietina (Müller) and other substrates J. mar. biol. Ass. U.K. 56, 291-303.

Yonge, C. M. 1968: Form and habit in species of Malleus (including the 'hammer oysters') with comparative observations on Isognomon isognomon. Biol. Bull. 135, 378-405.

\section{Appendix}

\section{Trace fossil taxonomy}

(see Figs 7-10)

Ancorichnus ancorichnus Heinberg 1974

Meniscus-filled tunnel with a peculiar mantle where mica flakes (when present) are oriented at an angle to the marginal mica flakes of the menisci. Width of trail between one and two centimetres. The trail is interpreted (Heinberg 1974) as reflecting the activity of a deposit-feeding animal. Common, but restricted to the western part of the area, it also occurs in the Pelion sandstone on Jameson Land (Heinberg 1969, Birkelund \& Heinberg 1974).

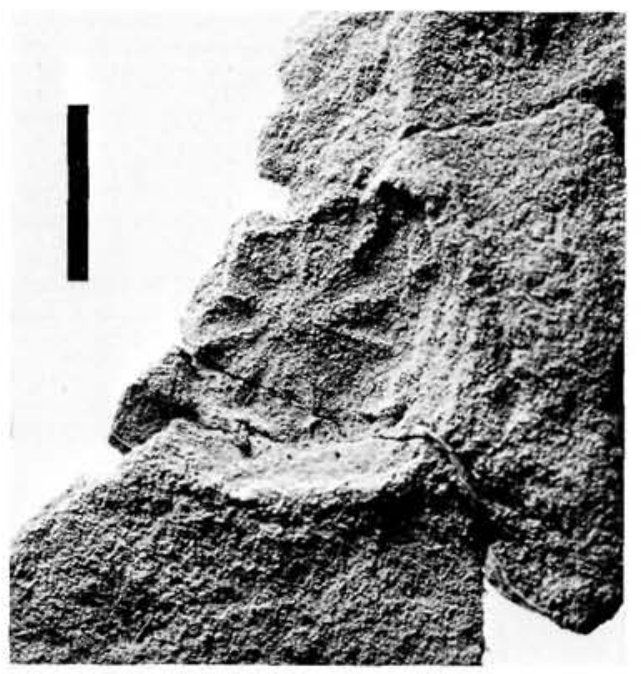

Fig. 29. Gyrophyllites Glocker 1841. Loose block from the beach north of Cardioceraskløft. Scale $1 \mathrm{~cm}$.

\section{Arenicolites Salter 1857}

Simple vertical U-tube without spreite. Produced by a suspension-feeding animal. Rare.

\section{Gyrophyllites Glocker 1841}

A loose block from the central part of the area yielded three specimens of a small star-like trace fossil. The trace consists of a circular depression, $2 \mathrm{~cm}$ wide and $0,5 \mathrm{~cm}$ deep (Fig. 29). The surface of the depression is characterised by a number $(8-12)$ of dark petal-like sections, which radiate from a indistinct knob in the centre. Each pair of 'petals' is separated by a narrow light ridge. The trace can be referred to Gyrophyllites, a radiating feeding burrow whereby radiating lobes are connected by a central vertical shaft (see Fürsich \& Kennedy, 1975 for reconstruction of the burrow).

\section{Curvolithus Fritsch 1908}

The positive trilobate epirelief consists of a broad median and two narrower smooth lateral ridges. The positive hyporelief consists of two narrow ridges separated by a wide flat groove.

The trace is thought to represent the activity of a carnivorous gastropod (Heinberg 1973). Culvolithus is the dominant trace fossil of the Pelion sandstone of Jameson Land, as well as of the Hartz Fjeld sandstone of Milne Land. The interpretation of the trail is based on extremely well preserved material from the latter.

Curvolithus is nearly always found together with Gyrochorte. It is common in the eastern part of the area.

\section{Gyrochorte Heer 1865}

The Gyrochorte trail is a penetrative structure which produces a double ridge on the upper surfaces of successive bedding planes. The trail is interpreted (Weiss 1940, 1941, Heinberg 1973) as reflecting the activity of an elongate organism moving sideways through the sediment in search of food. Common throughout the area.

\section{Helminthopsis Heer 1877}

Loosely meandering trail produced by an infaunal depositfeeder (Fig. 10). The trail has a width of 2-3 mm. Common throughout the area. 
Macaronichnus segregatis Clifton \& Thompson 1978

(= 'small meniscus tunnels' of Heinberg (1973))

Small, simple, sinuous, circular tubes, 0.1 to $0.2 \mathrm{~cm}$ in diameter which penetrate the sediment in all possible directions. Frequently with meniscus backfill structures. In most cases the fill has a light colour owing to lack of mica. Interpreted by Clifton \& Thompson (1978) as the burrows of infaunal deposit-feeding polychaetes. Similar traces are known from modern intertidal and shallow subtidal environments.

Common, but restricted to the western part of the area.

\section{Muensteria Sternberg 1833}

Meniscus-filled tunnel. Width of burrow $2.5 \mathrm{~cm}$. The burrows in the Aldinger Elv sandstone have been interpreted as reflecting the burrowing or ploughing activity of an echinoid (Heinberg) 1973). Rare.

\section{Planolites Nicholson 1873}

A simple tunnel with a circular cross-section. Width of trail $3.5 \mathrm{~mm}$; characteristic are its uniform width which is somewhat small for the ichnogenus and its light colour. The peculiar colouring is caused by a complete lack of mica in the burrow as opposed to the surrounding sediment. The burrow is interpreted as the product of a deposit-feeding organism (Pemberton \& Frey 1982).

\section{Skolithos Haldeman 1840}

Simple vertical tubes, produced by a suspension-feeding organism.

Sometimes with funnel at top ('Monocraterion'). Rare, restricted mainly to the upper boundary of the sandstone.

Thalassinoides suevicus Rieth 1932

Horizontal tunnel systems branching in a Y-shaped fashion. Produced by decapod crustaceans, possibly deposit-feeders (e.g. Bromley \& Asgaard 1972, Fürsich 1974).
Common, but restricted to the interbedded sandstone/ mudstone facies.

Urohelminthoida Sacco 1888

Meanders, 2-3 mm in diameter, with tail-like appendage at each turn; convex hyporelief. Graphoglyptid burrow (Fig. 10). Common on bedding planes at locality 3 .

Occurrence of Helminthopsis and Urohelminthoida in the Aldinger Elv Member:

Aldinger Elv Member:

Both Helminthopsis and Urohelminthoida are typical of flysch deposits rather than of shallow-water sand bodies (e.g. Ksiazkiewicz 1970). The loosely meandering trail of Helminthopsis can be interpreted as a feeding burrow, whilst the zigzag pattern and presence of short side branches identify Urohelminthoida as a graphoglyptid burrow. The latter is thought to represent open burrow systems serving as traps which were searched repeatedly by the animal for food particles such as bacteria or fungi (Seilacher 1977). Their unexpected appearance in the Aldinger Elv Member can be explained by analogy to the spiral tunnel systems of Paraonis fulgens on Recent tidal flats (Röder 1971): Paraonis constructs an open tunnel system in order to feed on diatoms which migrate from the sediment into the open tunnels.

Being the exception rather than the rule, the presence of a complex behaviour pattern in very shallow water environments does not contradict the usefulness of graphoglyptids as deep sea facies indicators, but may reflect frequent reworking of the substrate in analogy to the environment of Paraonis fulgens. 